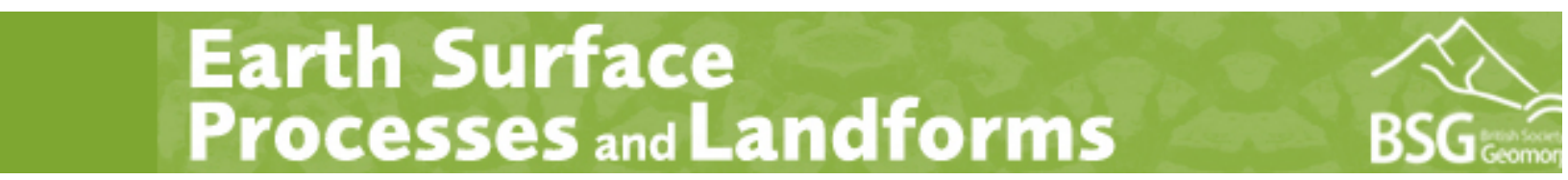

\title{
Subglacial bedform sensitivity to bed characteristics across the deglaciated Northern Hemisphere
}

\begin{tabular}{|c|c|}
\hline Journal: & Earth Surface Processes and Landforms \\
\hline Manuscript ID & Draft \\
\hline Wiley - Manuscript type: & Research Article \\
\hline Keywords: & $\begin{array}{l}\text { geomorphology, glacial landforms, ice flow, topography, lithology, ice } \\
\text { sheet }\end{array}$ \\
\hline Abstract: & $\begin{array}{l}\text { Streamlined subglacial bedforms observed in deglaciated landscapes } \\
\text { provide the opportunity to assess the sensitivity of ice dynamics to bed } \\
\text { characteristics across broader spatiotemporal scales than is possible for } \\
\text { contemporary glacial systems. While many studies of streamlined } \\
\text { subglacial bedforms rely on manual mapping and qualitative (i.e., visual) } \\
\text { assessment, we semi-automatically identify } 11,628 \text { erosional and } \\
\text { depositional bedforms, created during and following the Last Glacial } \\
\text { Maximum, across nine geologic and topographically diverse deglaciated } \\
\text { sites in the Northern Hemisphere. Using this large dataset of landforms } \\
\text { and associated morphometrics, we empirically test the importance of } \\
\text { subglacial terrain on bedform morphology and ice-flow behavior. A } \\
\text { minimum bedform length-width ratio threshold systematically provides a } \\
\text { constraint on landform elongation during genesis and minimum } \\
\text { morphometrics needed to resolve such bedforms in remote sensing data. } \\
\text { Distribution ranges of bedform elongations are remarkably similar across } \\
\text { all sites regardless of bed characteristics. These similarities in bedform } \\
\text { metrics regardless of bed properties indicate all bed types may support } \\
\text { streaming ice conditions. Regionally-constrained topography and easily } \\
\text { erodible beds host the most elongate bedforms yet the widest range in } \\
\text { bedform elongation and surface relief. This suggests higher ice-flow } \\
\text { velocities and continuity of flow paths despite spatially heterogeneous } \\
\text { landform-generating processes. In contrast, regions with unconstrained } \\
\text { topography and lithified sedimentary beds contain high conformity in } \\
\text { bedform density, relief, and elongation, indicating more spatially } \\
\text { homogeneous interactions at the ice-bed interface and consistency in } \\
\text { ice-flow velocity. Regardless of whether bedforms are erosional or } \\
\text { depositional products, we ultimately find a relatively higher sensitivity of } \\
\text { bedform elongation (i.e., ice streaming speed) to regional topography } \\
\text { while bedform density is more sensitive to bed lithology. The findings } \\
\text { presented here should be extrapolated to interpret processes of } \\
\text { subglacial erosion and deposition, ice-bed interactions, and streaming ice } \\
\text { flow within contemporary glacial systems. }\end{array}$ \\
\hline
\end{tabular}

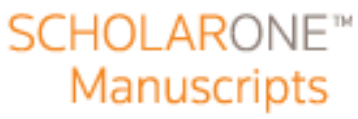




\title{
FILE 1: TITLE PAGE
}

\section{Subglacial bedform sensitivity to bed characteristics across the deglaciated Northern Hemisphere}

\author{
Marion A. McKenzie ${ }^{1}$, Lauren M. Simkins ${ }^{1}$, Sarah M. Principato ${ }^{2}$ \\ ${ }^{1}$ University of Virginia, Department of Environmental Sciences \\ ${ }^{2}$ Gettysburg College, Environmental Studies Department
}

Contact: mm8dt@virginia.edu; Isimkins@virginia.edu;

sprincip@gettysburg.edu

\section{ACKNOWLEDGEMENTS}

We acknowledge WADNR, USGS, and the Polar Geospatial Data Center data sources as well as A. Weiss, S. Tagil and J. Jenness for making their data and code accessible. Much of the data analysis and interpretation presented in this study was conducted in Charlottesville, Virginia on land that the Monacan Nation has protected and cultivated for thousands of years, and the authors acknowledge their ongoing stewardship of the lands. The authors have no conflict of interest to declare.

FUNDING: This work was funded by the Chamberlain Endowment and the H.G. Goodell Endowment at the University of Virginia.

\section{AUTHOR CONTRIBUTIONS}

Project conceptualization, data curation, methodology, formal analysis, writinginitial draft, writing-review and editing were conducted by M. McKenzie. Conceptualization, funding acquisition, formal analysis, writing-review and editing, and supervision were conducted by L. Simkins. Partial conceptualization, writingreview and editing were conducted by S. Principato.

\section{DATA AVAILABILITY STATEMENT}

The datasets generated from this work are available on Pangaea Data Publisher for Earth and Environmental Science Repository (submitted October 25th , 2021; waiting on DOI). Published data include shapefiles of streamlined subglacial bedforms from the sites assessed in this work, an Excel file with all bedform morphometric raw data, and the ArcPython and toolbox file for the topographic position index (TPI) semi-automated landscape mapping tool.

All data generated stem from publicly available digital elevation models (DEMs) from Clallam County, 2005 for the Puget Lowland, Washington, United States site (https://lidarportal.dnr.wa.gov/\#47.85003:-122.92053:7). The ArcticDEM data center was utilized for the M'Clintock Channel, Canada; Prince of Wales Island, Canada; Nunavut, Canada; Bárðardalur, Iceland; northern Norway; and northern Sweden sites (Porter et al., 2018; https://doi.org/10.7910/DVN/OHHUKH). United States Geological Society DEMs from 1999 and 2000 were used for the northwestern Pennsylvania, United States (http://www.pasda.psu.edu/) and Chautauqua, New York, United States sites (https://apps. nationalmap.gov/viewer/), respectively. 


\title{
FILE 2: MAIN DOCUMENT
}

\section{Streamlined subglacial bedform sensitivity to bed characteristics across the deglaciated Northern Hemisphere}

\begin{abstract}
(up to 300 words)
Streamlined subglacial bedforms observed in deglaciated landscapes provide the opportunity to assess the sensitivity of ice dynamics to bed characteristics across broader spatiotemporal scales than is possible for contemporary glacial systems. While many studies of streamlined subglacial bedforms rely on manual mapping and qualitative (i.e., visual) assessment, we semi-automatically identify 11,628 erosional and depositional bedforms, created during and following the Last Glacial Maximum, across nine geologic and topographically diverse deglaciated sites in the Northern Hemisphere. Using this large dataset of landforms and associated morphometrics, we empirically test the importance of subglacial terrain on bedform morphology and ice-flow behavior. A minimum bedform length-width ratio threshold systematically provides a constraint on landform elongation during genesis and minimum morphometrics needed to resolve such bedforms in remote sensing data. Distribution ranges of bedform elongations are remarkably similar across all sites regardless of bed characteristics. These similarities in bedform metrics regardless of bed properties indicate all bed types may support streaming ice conditions. Regionally-constrained topography and easily erodible beds host the most elongate bedforms yet the widest range in bedform elongation and surface relief. This suggests higher ice-flow velocities and continuity of flow paths despite spatially heterogeneous landform-generating processes. In contrast, regions with unconstrained topography and lithified sedimentary beds contain high conformity in bedform density, relief, and elongation, indicating more spatially homogeneous interactions at the ice-bed interface and consistency in iceflow velocity. Regardless of whether bedforms are erosional or depositional products, we ultimately find a relatively higher sensitivity of bedform elongation (i.e., ice streaming speed) to regional topography while bedform density is more sensitive to bed lithology. The findings presented here should be extrapolated to interpret processes of subglacial erosion and deposition, ice-bed interactions, and streaming ice flow within contemporary glacial systems.
\end{abstract}

Keywords: geomorphology, glacial landforms, ice flow, topography, lithology, ice sheet 


\section{INTRODUCTION}

Understanding the conditions that control ice-sheet flow is particularly important for ice streams, conduits of fast-flowing ice at rates of $10^{2}-10^{3} \mathrm{~m} \mathrm{a}^{-1}$, due to their ability to efficiently drain and destabilize glacial catchments and dictate glacial contributions to sea level (Bamber \& Aspinall, 2013; Serrousi et al., 2017; Rignot et al., 2019). The character of the underlying terrain (i.e., bed) beneath ice streams influences iceflow velocity and organization by modulating driving stresses, meltwater production and transmission (Hindmarsh, 2001; Wellner et al., 2001; Hall and Glasser, 2003; Falcini et al., 2018: Maier et al., 2019; Greenwood et al., 2021), and spatial variations in ice thickness (Payne \& Dongelmans, 1997; Roberts et al., 2010; Eyles et al., 2018). Patterns and rates of ice flow are commonly linked to known or perceived properties of the bed including topography and lithology (Clarke et al., 1977; Whillians \& van der Veen, 1997; Cuffey \& Paterson, 2010). These properties can have opposing effects and varying degrees of influence on ice-stream behavior (De Rydt et al., 2013; Falcini et al., 2018; Greenwood et al., 2021).

Areas with negative topographic relief (i.e., valleys and troughs) in both marine and terrestrial-based glacial systems have the potential to increase ice streaming due to syphoning and thickening of ice, leading to increased pressure melting and overall meltwater abundance that enhance basal sliding and/or sediment deformation (Hindmarsh, 2001; Eyles et al., 2018). Similarly, ice flow is accelerated through strain heating of basal ice (McIntyre, 1985; Pohjola \& Hedfors, 2003; Winsborrow et al., 2010b) in areas of positive topographic relief (i.e., pinning points, ridges, and banks) and regions of high bed roughness (i.e., spatial variation in surface elevation and slope; Siegert et al., 2005; Rippin et al., 2011; Falcini et al., 2018). Yet, in other circumstances, obstacles in the bed and confined topography can enhance basal and lateral drag, leading to slower ice flow and potential grounding-line stabilization in marine-terminating systems (Favier et al., 2016; Falcini et al., 2018; Whillans \& van der Veen, 1997).

Bed lithology also plays a fundamental role in ice-bed coupling, efficiency of meltwater transmission, and sedimentary processes such as deformation, erosion, and deposition (Weertman, 1957). Permeable unlithified sedimentary beds allow for water infiltration and enhanced ice motion due to sediment deformation (Alley et al., 1986; Tulaczyk et al., 2000; Cuffey \& Paterson, 2010) whereas more impermeable, "hard" beds favor the formation of water films that induce basal sliding (Evans et al., 2006; Nienow et al., 2017). Bed lithology also impacts rates of erosion and deposition in the subglacial environment due to its control on meltwater transmission and relative hardness differences between the bed and basal ice (Ng, 1998; Fowler, 2010).

Erosion and deposition at the ice-bed interface can create subglacial streamlined bedforms, elongate in the direction of ice flow, which are useful indicators of subglacial processes and ice flow across landscapes (Stokes \& Clark, 2001, 2002; King et al., 2009). Hypothesized formative 
91 processes of streamlined bedforms include bed erosion by meltwater

92 (Shaw et al., 2008), ice-keel ploughing (Tulczyk et al., 2001; Clark et al., 93 2003), spatially heterogeneous sediment deposition due to orthogonal basal pressure variability (Schoof \& Clark, 2008), and till deformation (King et al., 2009). Many bedform types, for example glacial lineations, are genetically and morphologically similar between paleo and contemporary glacial systems (King et al., 2009); therefore, the location of paleo-ice streams is interpreted from streamlined bedforms (e.g. Clark, 1993; Bourgeois et al., 2000; Stokes \& Clark, 2001; Clark et al., 2003; Briner, 2007; Ottesen et al., 2008; Stokes et al., 2013, Spagnolo et al., 2014; Principato et al., 2016). Streamlined bedforms are commonly well preserved and mark the final or most prominent phase of ice flow across the landscape (Clark, 1999; Winsborrow et al., 2010b). While streamlined bedforms range in size from centimeters to several kilometers in length and centimeters to tens of meters in amplitude, the elongation (i.e. ratio of length to width) of bedforms is commonly used to infer characteristics of ice-streaming speed and direction in deglaciated landscapes.

Qualitative (i.e., visually descriptive) assessment of streamlined bedforms in deglaciated landscapes is used to interpret ice-flow behavior and aid in understanding ice-bed interactions applicable to contemporary glacial systems (e.g., Eyles et al., 2018; Greenwood et al., 2021). Yet, quantitative (i.e., morphometric and statistical) analysis of streamlined bedforms is more arduous as these bedforms have low, even sub-meter vertical relief and typically occur in "swarms" of tens to thousands of bedforms (Hughes et al., 2010; Ely et al., 2016). Additionally, few automated bedform identification methodologies have been developed for glacial landscapes and an even smaller subset have been systematically applied across multiple sites (e.g., Cazenave et al., 2008; Saha et al., 2011; Wang et al., 2017; Spagnolo et al., 2017). This study uses topographic positioning index (TPI; Weiss, 2001; Tagil and Jenness, 2008) to calculate "neighborhood" elevation and slope variations to semiautomatically identify subglacial streamlined bedforms from nine deglaciated landscapes in the Northern Hemisphere (Figure 1). This large, geographically diverse dataset of streamlined bedforms is unique in that it contains both depositional and erosional forms associated with ice flow of four former ice sheets. We aim to identify the sensitivity of ice streaming to variable bed conditions as inferred from bedform relationships with bed topography and lithology. 


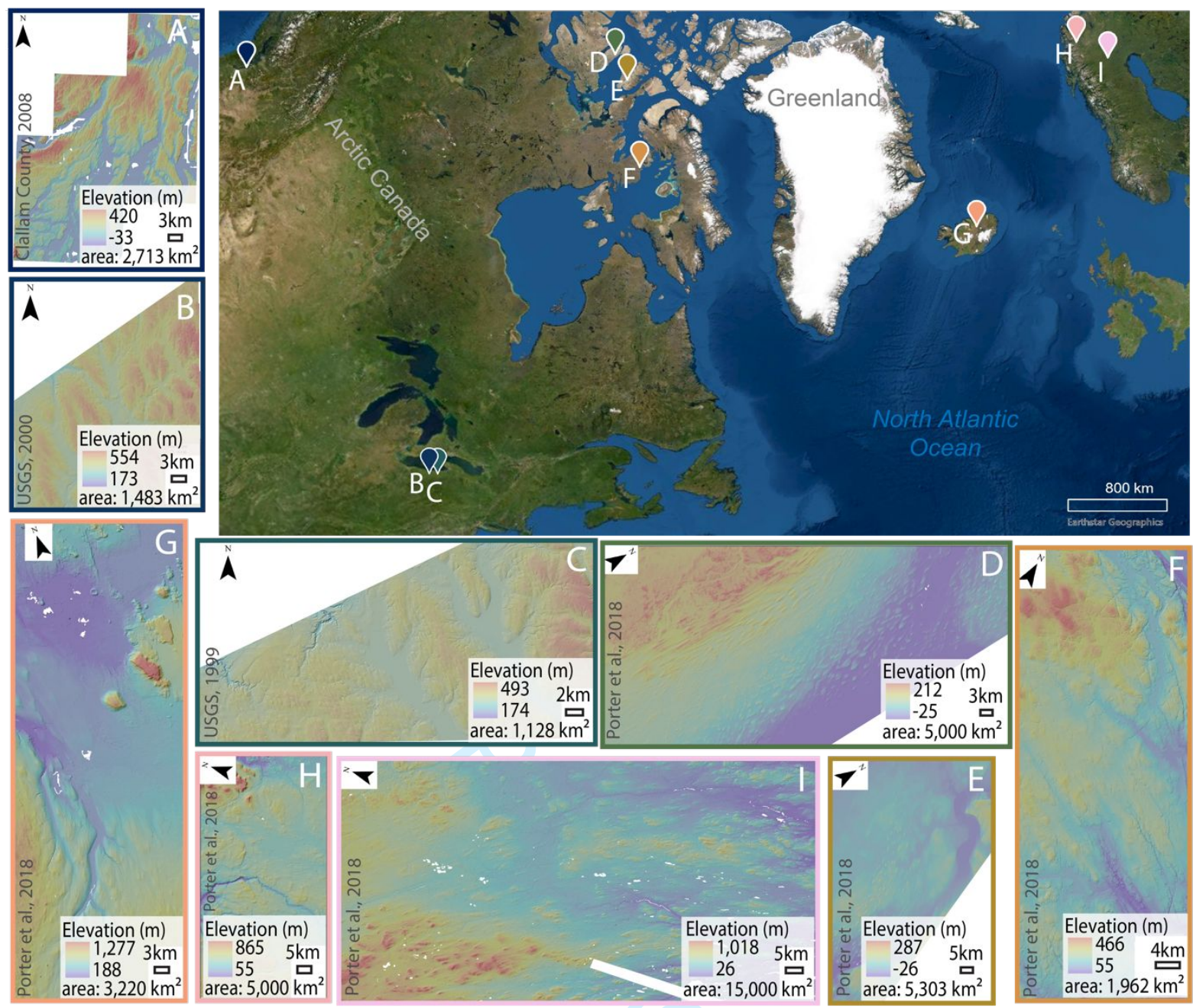

Figure 1: Study sites including (A) Puget Lowland, Washington, United States; (B) Northwestern Pennsylvania, United States; (C) Chautauqua, New York, United States; (D) M'Clintock Channel, Canada; (E) Prince of Wales Island, Canada; (F) Nunavut, Canada; (G) Bárðardalur, Iceland; (H) Northern Norway; (I) Northern Sweden.

\section{METHODOLOGY AND METHODS}

The land-surface areas of each of the nine study sites range from 1,128$15,000 \mathrm{~km}^{2}$ and include (A) the Puget Lowland in Washington, United States formerly glaciated by the southern Cordilleran Ice Sheet (CIS); (B) Northwestern Pennsylvania, United States and (C) Chautauqua, New York, United States glaciated by the southern Laurentide Ice Sheet (LIS); (D) M'Clintock Channel, Canada, (E) Prince of Wales Island, Canada, and (F) Nunavut, Canada glaciated by interior ice streams of the LIS; (G) Bárðardalur, Iceland glaciated by the Icelandic Ice Sheet; and $(\mathrm{H})$ Northern Norway and (I) Northern Sweden glaciated by ice streams of the Fennoscandian Ice Sheet (Figure 1; Table 1). All sites were glaciated during the Last Glacial Maximum (LGM, 23,000-19,000 years ago; Hughes et al., 2013); therefore, the surface-exposed streamlined bedforms represent LGM and post-LGM ice flow, yet some bedforms may have formed or been influenced by earlier glaciations. Because this processbased study focuses on bedform morphology and distribution, absolute age determinations or associations (i.e., when the bedforms formed or when the sites were deglaciated) are beyond the scope of this project. 
Extensive efforts by state and federal agencies to collect highresolution digital elevation data allow for glacial landforms, formed directly by ice-sheet advance and retreat across the landscape, to be mapped at unprecedented spatial scales. Bed topography and lithology at each site was classified by publicly available digital elevation models (DEMs) ranging from $2 \mathrm{~m}$ vertical and $1.83 \times 1.83 \mathrm{~m}$ horizontal resolution to $2 \mathrm{~m}$ vertical and $2 \times 2 \mathrm{~m}$ horizontal resolution as well as regional geology maps (USGS 1999; 2000; Clallam County, 2008; Porter et al., 2018). While the present-day elevations differ from elevations at the time of glaciation due to GIA, tectonics, and post-glacial landscape erosion and deposition, we classified topographic setting in the broadest sense as either "constrained" or "unconstrained" on spatial scales of $10^{1-10^{2}} \mathrm{~km}$ (Payne \& Dongelmans, 1997). "Constrained" topography is defined as low elevation surrounded by more elevated regions and "unconstrained" defined as open, relatively uniform topography. Bed lithology was generally and regionally classified as "lithified sedimentary", "unlithified sedimentary", "crystalline", "volcanic", or "mixed" bed and describes the bed conditions in which overlying ice would have been in contact with at the time of glaciation.

Table 1: Site descriptions and data information.

\begin{tabular}{|c|c|c|c|c|c|c|c|c|}
\hline Sites & $\begin{array}{l}\begin{array}{l}\text { Latitude } \\
\text { (decimal } \\
\text { degrees) }\end{array} \\
\end{array}$ & Bed setting & $\begin{array}{l}\text { Topographic } \\
\text { setting }\end{array}$ & Glacial history & $\begin{array}{l}\text { LGM climate } \\
\text { conditions }\end{array}$ & $\begin{array}{l}\text { Land } \\
\text { surface } \\
\text { area }\left(\mathbf{k m}^{2}\right)\end{array}$ & $\begin{array}{l}\text { Vertical } \\
\text { resolution } \\
\text { (m) }\end{array}$ & $\begin{array}{l}\text { Horizontal } \\
\text { resolution } \\
(\mathrm{m} \times \mathrm{m})\end{array}$ \\
\hline $\begin{array}{l}\text { (A) Puget } \\
\text { Lowland, } \\
\text { Washington } \\
\text { State }\end{array}$ & 47.3507 & mixed & constrained & $\begin{array}{l}\text { ice free from the Cordilleran } \\
\text { Ice Sheet for } 16.5 \mathrm{ky} \text { a.,.,c, } \\
\text { near ice margin, marine } \\
\text { terminating }\end{array}$ & $\begin{array}{l}\text { maritime, complex } \\
\text { seasonal climate } \\
\text { shifts }^{\mathrm{d}, \mathrm{e}}\end{array}$ & 2,713 & 2 & $1.83 \times 1.83$ \\
\hline $\begin{array}{l}\text { (B) } \\
\text { Northwestern } \\
\text { Pennsylvania }\end{array}$ & 41.9456 & $\begin{array}{l}\text { lithified } \\
\text { sedimentary bed }\end{array}$ & unconstrained & $\begin{array}{l}\text { ice free from the Laurentide } \\
\text { Ice Sheet for } 17 \mathrm{ky} \text {,' near } \\
\text { ice margin, terrestrially } \\
\text { terminating }\end{array}$ & $\begin{array}{l}\text { continental, stable } \\
\text { climate }^{9}\end{array}$ & 1,483 & 10 & $30 \times 30$ \\
\hline $\begin{array}{l}\text { (C) Chautauqua, } \\
\text { New York }\end{array}$ & 42.2263 & $\begin{array}{l}\text { lithified } \\
\text { sedimentary bed }\end{array}$ & unconstrained & $\begin{array}{l}\text { ice free from the Laurentide } \\
\text { Ice Sheet for } 17 \mathrm{ky} \text { ', near } \\
\text { ice margin, terrestrially } \\
\text { terminating }\end{array}$ & $\begin{array}{l}\text { continental } \\
\text { climate, high } \\
\text { winds }^{9}\end{array}$ & 1,128 & 10 & $30 \times 30$ \\
\hline $\begin{array}{l}\text { (D) M'Clintock } \\
\text { Channel, } \\
\text { Canada }\end{array}$ & 72.6689 & $\begin{array}{l}\text { lithified } \\
\text { sedimentary bed }\end{array}$ & unconstrained & $\begin{array}{l}\text { ice free from the Laurentide } \\
\text { Ice Sheet for at least } 9 \mathrm{ky}^{n} \text {, } \\
\text { interior ice stream }\end{array}$ & $\begin{array}{l}\text { continental } \\
\text { climate }^{9}\end{array}$ & 5,000 & 2 & $2 \times 2$ \\
\hline $\begin{array}{l}\text { (E) Prince of } \\
\text { Wales Island, } \\
\text { Canada }\end{array}$ & 72.3189 & $\begin{array}{l}\text { lithified } \\
\text { sedimentary bed }\end{array}$ & unconstrained & $\begin{array}{l}\text { ice free from the Laurentide } \\
\text { Ice Sheet for } 7 \mathrm{ky} \mathrm{yy}^{\prime} \text {, interior } \\
\text { ice stream' }\end{array}$ & $\begin{array}{l}\text { continental } \\
\text { climate }^{9}\end{array}$ & 5,303 & 2 & $2 \times 2$ \\
\hline $\begin{array}{l}\text { (F) Nunavut, } \\
\text { Canada }\end{array}$ & 69.4173 & crystalline bed & unconstrained & $\begin{array}{l}\text { ice free from the Laurentide } \\
\text { lce Sheet for } 7 \mathrm{ky}^{\natural} \text {, interior } \\
\text { ice stream| }\end{array}$ & $\begin{array}{l}\text { continental } \\
\text { climate, high } \\
\text { winds }\end{array}$ & 1,962 & 2 & $2 \times 2$ \\
\hline $\begin{array}{l}\text { (G) Bárđardalur, } \\
\text { Iceland }\end{array}$ & 65.3055 & volcanic bed & constrained & $\begin{array}{l}\text { ice free from the Icelandic } \\
\text { Ice Sheet for } 14 \mathrm{kyh} \text { near } \\
\text { ice margin, marine } \\
\text { terminating }\end{array}$ & maritime climate & 3,220 & 2 & $2 \times 2$ \\
\hline $\begin{array}{l}\text { (H) Northern } \\
\text { Norway }\end{array}$ & 69.0897 & crystalline bed & constrained & $\begin{array}{l}\text { ice free from the } \\
\text { Fennoscandian Ice Sheet } \\
\text { for at least } 18 \mathrm{ky} y^{h}, \text { near ice } \\
\text { margin, marine terminating }\end{array}$ & maritime climate & 5,000 & 2 & $2 \times 2$ \\
\hline $\begin{array}{l}\text { (I) Northern } \\
\text { Sweden }\end{array}$ & 67.1265 & crystalline bed & unconstrained & $\begin{array}{l}\text { ice free from the } \\
\text { Fennoscandian Ice Sheet } \\
\text { for at least } 18 \mathrm{ky} \text {, interior } \\
\text { ice stream }\end{array}$ & maritime climate & 15,000 & 2 & $2 \times 2$ \\
\hline
\end{tabular}

We mapped streamlined bedforms from the nine sites with a combination of manual identification and TPI, originally developed by Weiss (2001) for the purpose of characterizing landscapes. TPI utilizes DEM cell elevation and mean elevation of a defined neighborhood to calculate slope variations across a landscape. Neighborhood sizes were determined by assessing the visible range in scales of bedforms present. At least two neighborhood assessments, ranging from 300 to 2,100 m, were conducted for each site in order to capture a range in landscape granularity. Using spatial analyst tools, all positive relief features identified by TPI, including non-subglacial streamlined bedforms, were merged into one polygon file (McKenzie et al., 2021). Thresholding of 
179 bedform metrics such as length, width, orientation, and area attributes

coupled with a manual assessment, conducted by visually removing incorrectly identified features and adding features missed by TPI, resulted in a more accurate dataset whose metrics were not influenced by morphometric threshold sorting (McKenzie et al., 2021).

For each mapped bedform, its long-axis length and orientation, width orthogonal to length, and minimum and maximum elevations (i.e., change in relief across individual bedform lengths) were calculated automatically in ArcGIS Pro using the 'Minimum Bounding Geometry' and 'Add Z Information' tools. Elevation changes across individual bedform materials and underlying local topography variations collectively manifest as the measurement of bedform relief. Automatic calculation of streamlined bedform length orientation is quantified in degrees, measured by the rotation of the bedform long axis from due north, and is used to infer direction of ice flow (Kleman \& Borgström, 1996; Clark, 1997; Kleman et al., 2006). Bedform elongation ratio, calculated by dividing the bedform length by its width, and parallel conformity (i.e., the standard deviation of bedform orientation) were calculated in MATLAB and used to infer both ice-flow velocity magnitude and persistence of ice-flow pathways where ranges in values are relatively small. The inclusivity of both erosional and depositional features is a strength to this study, as it allows for the assessment of topographic and lithologic controls on ice streaming regardless of landform-generating processes.

\section{RESULTS}

In the following sub-sections, we describe the utility of TPI in identifying streamlined subglacial bedforms, the trends and correlations of bedform morphology, the occurrence and morphology of bedforms with respect to bed topography and lithology, and finally, describe the relationship between spatial orientation and distribution of bedforms across the nine sites.

\section{Streamlined subglacial bedform identification}

Across the nine sites, TPI identified 7,635 bedforms while 3,993 bedforms were manually mapped (i.e., added or adjusted from TPI mapping), resulting in a total dataset of 11,628 bedforms (Figure 2 ). The M'Clintock Channel (Site D) and Puget Lowland (Site A) sites have the greatest number of bedforms correctly identified by TPI, requiring a lower proportion number of bedforms to be manually mapped (Table 2). However, TPI struggled to correctly identify bedforms in northern Sweden (Site I), where the number of incorrectly identified bedforms exceeded the number of those that were correctly identified. Additionally, sites with the greatest number of bedforms manually added to the final dataset include northern Norway (Site H) and northern Sweden (Site I). Sites with relatively uniform, high amplitude and evenly spaced bedforms, such as those in northwestern Pennsylvania (Site B) and Chautauqua (Site C), 
2).
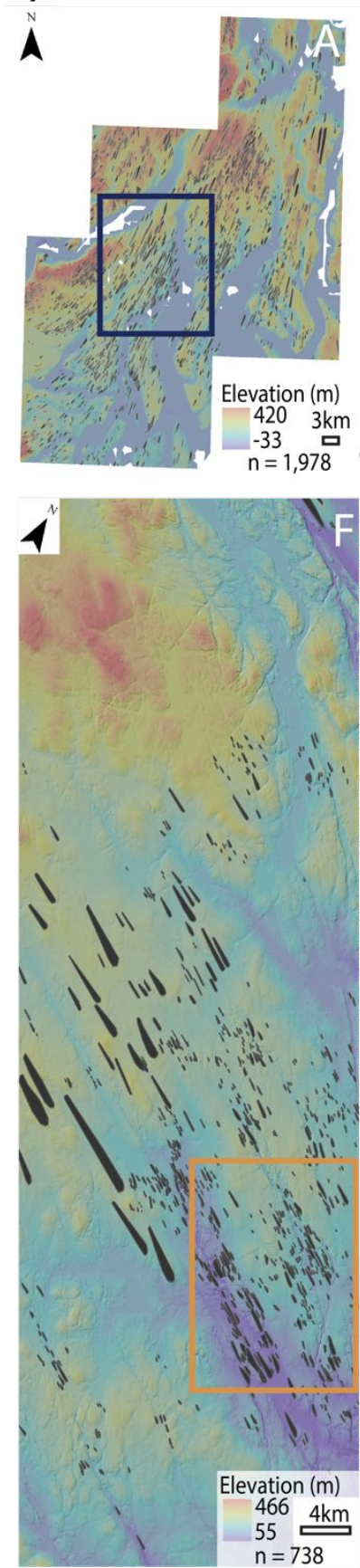
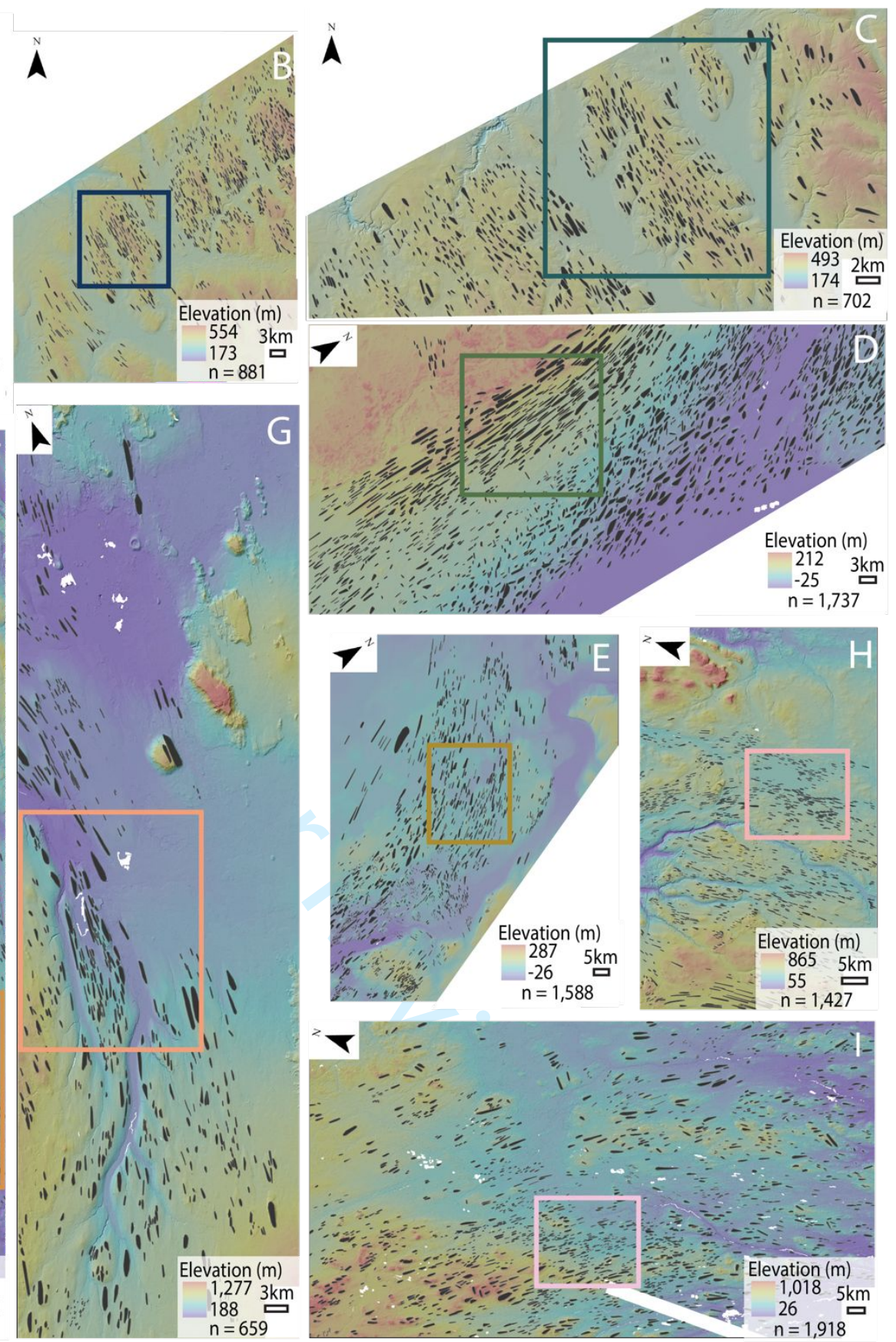

Figure 2: Mapped streamlined bedforms (black polygons) using topographic position index (TPI) methodology. Sites include (A) Puget Lowland, Washington, United States; (B) Northwestern Pennsylvania, United States; (C) Chautauqua, New York, United States; (D) M'Clintock Channel, Canada; (E) Prince of Wales Island, Canada; (F) Nunavut, Canada; (G) Bárðardalur, Iceland; (H) Northern Norway; (I) Northern Sweden. Colored insets indicate elongation distribution, pictured in Figure 8. 
Table 2: Bedform data by site including mapping statistics and bedform metrics.

\begin{tabular}{|c|c|c|c|c|c|c|c|}
\hline Sites & $\begin{array}{l}\text { Number of } \\
\text { bedforms (number } \\
\text { removed ; number } \\
\text { added) }\end{array}$ & $\begin{array}{l}\text { Bedforms } \\
\text { per } 10 \mathrm{~km}^{2}\end{array}$ & $\begin{array}{l}\text { Ratio of } \\
\text { manually } \\
\text { added } \\
\text { bedforms: } \\
\text { final } \\
\text { bedforms }\end{array}$ & $\begin{array}{l}\text { Average } \\
\text { length } \pm \\
\text { standard } \\
\text { deviation }\end{array}$ & $\begin{array}{l}\text { Average } \\
\text { width } \pm \\
\text { standard } \\
\text { deviation }\end{array}$ & $\begin{array}{l}\text { Average } \\
\text { elongation }\end{array}$ & $\begin{array}{l}\text { Average } \\
\text { orientation } \pm \\
\text { parallel } \\
\text { conformity }\end{array}$ \\
\hline (A) Puget Lowland, Washington State & $1,978(512 ; 401)$ & 7.3 & $0.2: 1$ & $2,013 \pm 1,261$ & $365 \pm 180$ & 5.9 & $214 \pm 27$ \\
\hline (B) Northwestern Pennsylvania & $881(774 ; 60)$ & 5.9 & $0.07: 1$ & $666 \pm 342$ & $162 \pm 69$ & 4.4 & $330 \pm 11$ \\
\hline (C) Chautauqua, New York & $702(493 ; 103)$ & 6.2 & $0.1: 1$ & $652 \pm 337$ & $164 \pm 77$ & 4.1 & $329 \pm 10$ \\
\hline (D) M'Clintock Channel, Canada & $1,737(333 ; 615)$ & 3.5 & $0.4: 1$ & $1,259 \pm 789$ & $278 \pm 153$ & 5.0 & $46 \pm 31$ \\
\hline (E) Prince of Wales Island, Canada & $1,588(1,657 ; 665)$ & 3.0 & $0.4: 1$ & $1,054 \pm 882$ & $224 \pm 162$ & 4.9 & $57 \pm 51$ \\
\hline (F) Nunavut, Canada & $738(>800 ; 155)$ & 3.8 & $0.2: 1$ & $617 \pm 614$ & $115 \pm 88$ & 5.4 & $150 \pm 7$ \\
\hline (G) Bárđardalur, Iceland & $659(745 ; 326)$ & 2.1 & $0.5: 1$ & $1,006 \pm 701$ & $175 \pm 125$ & 6.6 & $132 \pm 59$ \\
\hline (H) Northern Norway & $1,427(526 ; 783)$ & 2.9 & $0.5: 1$ & $842 \pm 580$ & $132 \pm 68$ & 6.9 & $102 \pm 17$ \\
\hline (I) Northern Sweden & $1,918(2,241 ; 858)$ & 1.3 & $0.5: 1$ & $1,324 \pm 794$ & $346 \pm 187$ & 4.1 & $255 \pm 19$ \\
\hline
\end{tabular}

Almost all scales of known streamlined bedforms (Ely et al., 2016) can be resolved by DEMs and identified by TPI, except for bedforms with low, millimeter to centimeter amplitudes. The mapped bedforms range in relief from $<1$ to about $500 \mathrm{~m}$, where bedform relief of $0 \mathrm{~m}$ reflects a flat bedform surface (Figure 3 ). The Puget Lowland (Site A), a topographically constrained mixed lithology site, has the greatest number of bedforms per area, followed by two sites that are topographically unconstrained with lithified sedimentary beds in Chautauqua (Site C) and northwestern Pennsylvania (Site B) (Table 2).

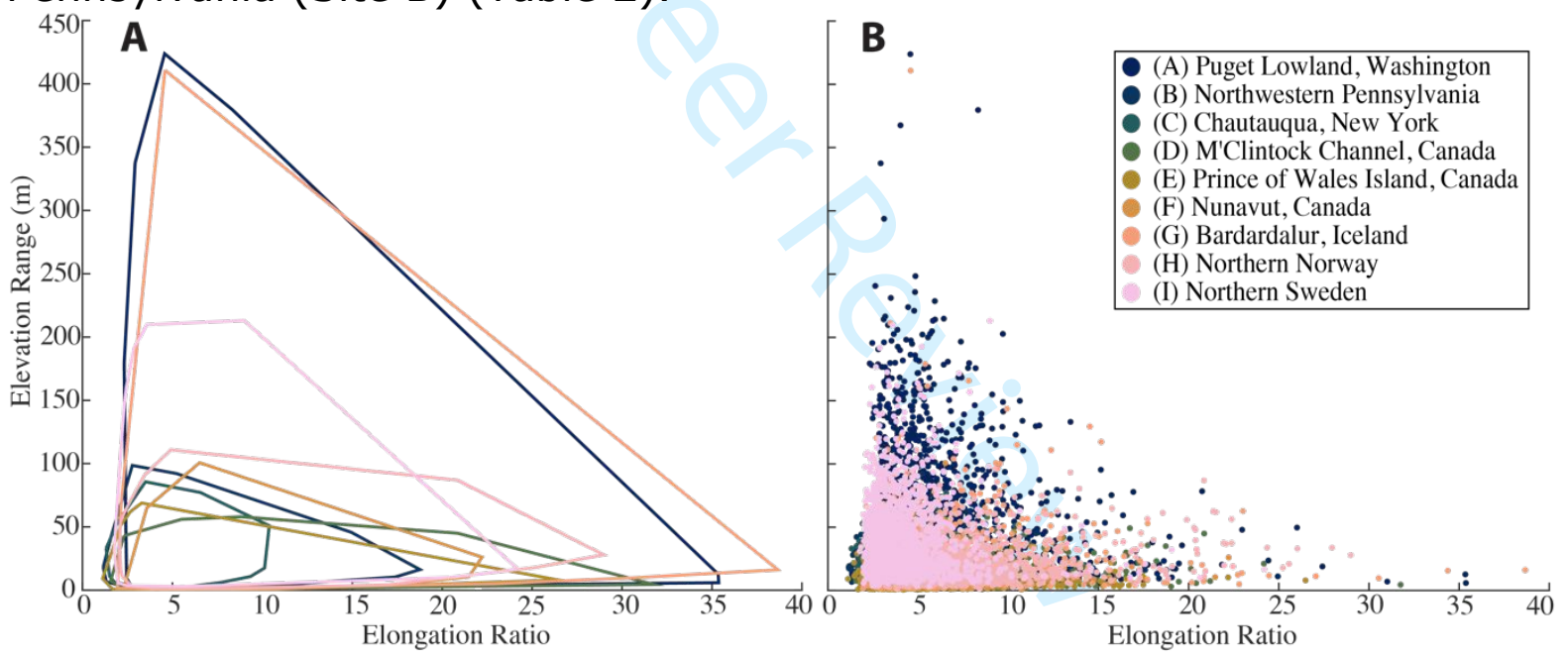

Figure 3: All bedform elongation ratio and elevation range metrics: (A) convex hull area of site data and (B) scatterplot of all data, $\mathrm{y}$-axis is the same as panel A. More elongate bedforms correspond with smaller bedform elevation range. Greater differences in bedform elevation correspond with lower elongation ratio values.

The streamlined bedforms range in length from 94 to $15,388 \mathrm{~m}$ (mean 1,052 m; median $754 \mathrm{~m}$ ) and in width from 19 to 2,323 m (mean $219 \mathrm{~m}$; median, $157 \mathrm{~m}$ ). The Puget Lowland (Site A) bedforms span the greatest range in width and length of all sites, while Chautauqua (Site C) bedform length versus width comparisons have the smallest range. While the bedforms with smaller widths and lengths at all sites overlap in range, there is less overlap of bedforms with lengths greater than 2,000 m (Figure 4A). A minimum threshold in bedform length to width appears for all sites, which indicates that length, at the very least, must be greater than width for streamlined bedforms to be identified and/or produced 
within resolution of bedforms resolvable in the DEMs. Consistency in peak elongation ratios for all sites is also observed, with a median elongation ratio of $5: 1$, rather than observing distinct (i.e., minimally or nonoverlapping) populations (Figure 5; Table 2). The degree of positive skewness of elongation, or the degree to which the distribution of data falls to the positive side of the bedform elongation mean, varies by site with sites Bárðardalur (Site G) and Puget Lowland (Site A) highly positively skew while sites Chautauqua (Site $C$ ) and northwestern Pennsylvania (Site B) are the least positively skewed.

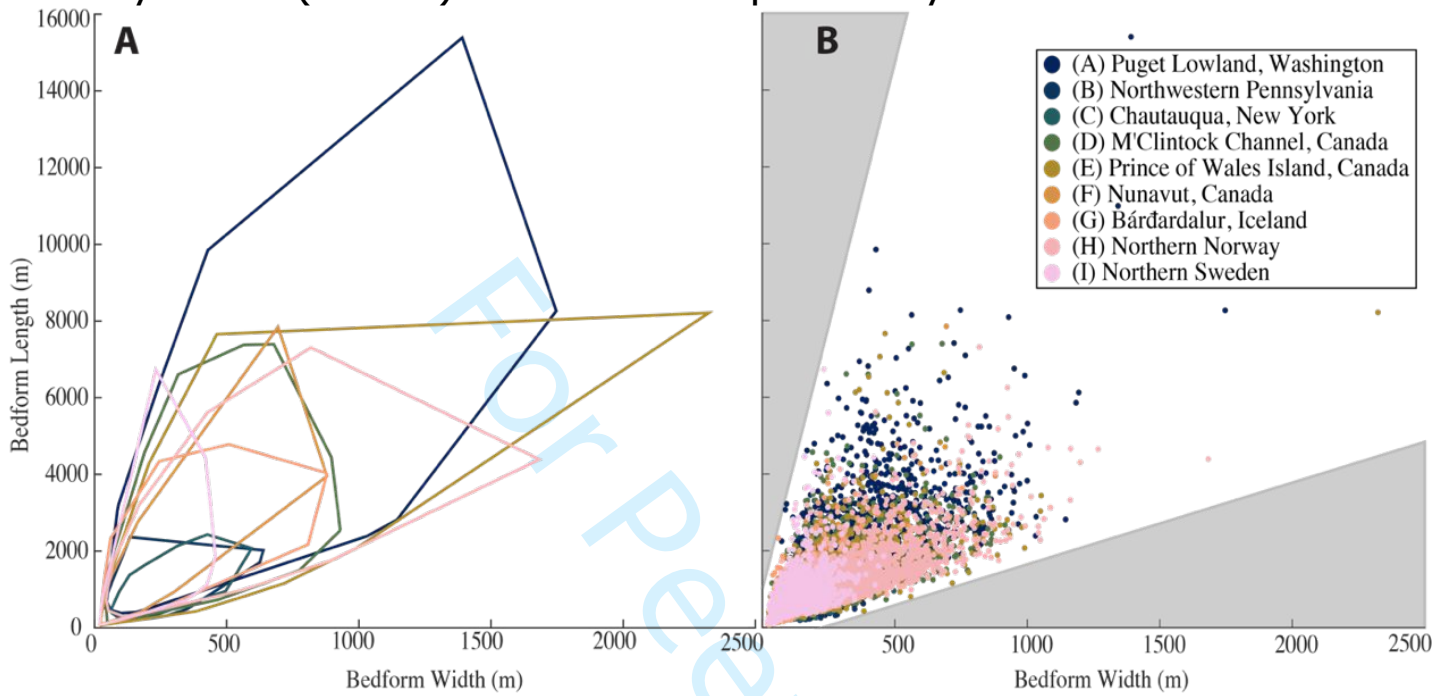

Figure 4: All bedform length and width metrics plotted by site: (A) convex hull area of site data and (B) scatterplot of all data, $\mathrm{y}$-axis is the same as panel A, gray areas indicate regions where bedforms are not observed. The mean and standard deviation of all bedform widths is $219 \pm 123 \mathrm{~m}$ while mean and standard deviation of all bedform lengths is $1,052 \pm 700 \mathrm{~m}$. Additional morphometric information for each site can be found in Table 2 .

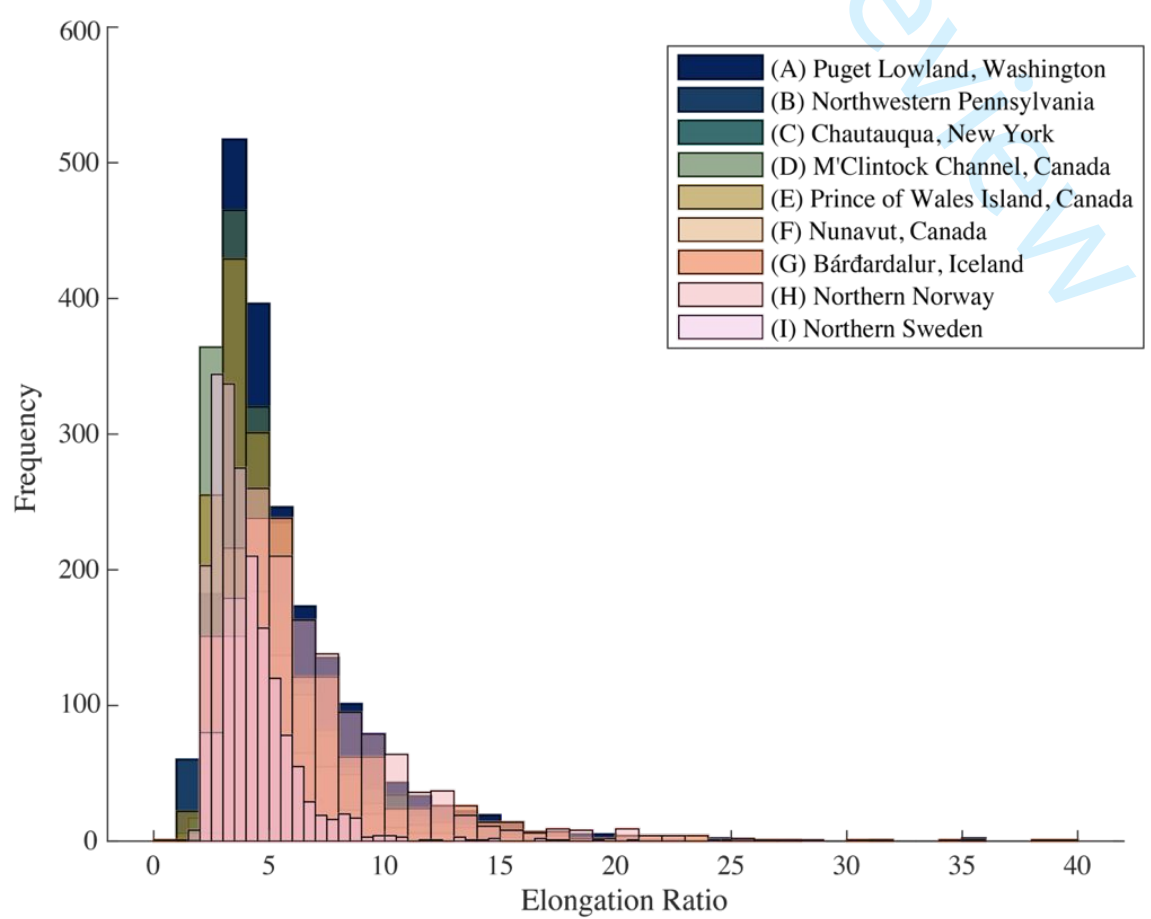

Figure 5: Frequency of bedform elongation ratios. Additional morphometric information for each site can be found in Table 2. Site-specific histogram bins were calculated through the MATLAB "histogram algorithm" utilizing site-specific minimum and maximum elongation values. 
The Puget Lowland (Site A) has the highest mean and median bedform relief range with the greatest range of values than any other site (Figure 6A; Hoffman, 2015). Prince of Wales Island (Site E), has the smallest mean and median bedform relief while M'Clintock Channel (Site D) has the smallest bedform relief of all sites (Figure 6A). The northern Norway (Site $\mathrm{H}$ ) site has the highest mean and median bedform elongation ratio values, while Bárðardalur (Site G) has the greatest range of elongation ratio of all sites (Figure 6B). Chautauqua (Site C) bedforms have the smallest elongation ratio mean, median, and range of all sites (Figure 6B). Overall trends indicate that when comparing individual bedform elongation and bedform relief, more elongate bedforms correspond with more uniform bedform relief (Figure 3). Conversely, less elongate bedforms display greater variation in individual bedform relief (Figure 3). Utilizing a linear Pearson correlation, bedform length and relief as well as site lithology and bedform relief have the highest positive correlation coefficients (Figure S1), while topography and lithology both have strong correlation to bedform width (Figure S1). Bedform length and elongation as well as bedform length and width are similarly positively correlated (Figure S1).

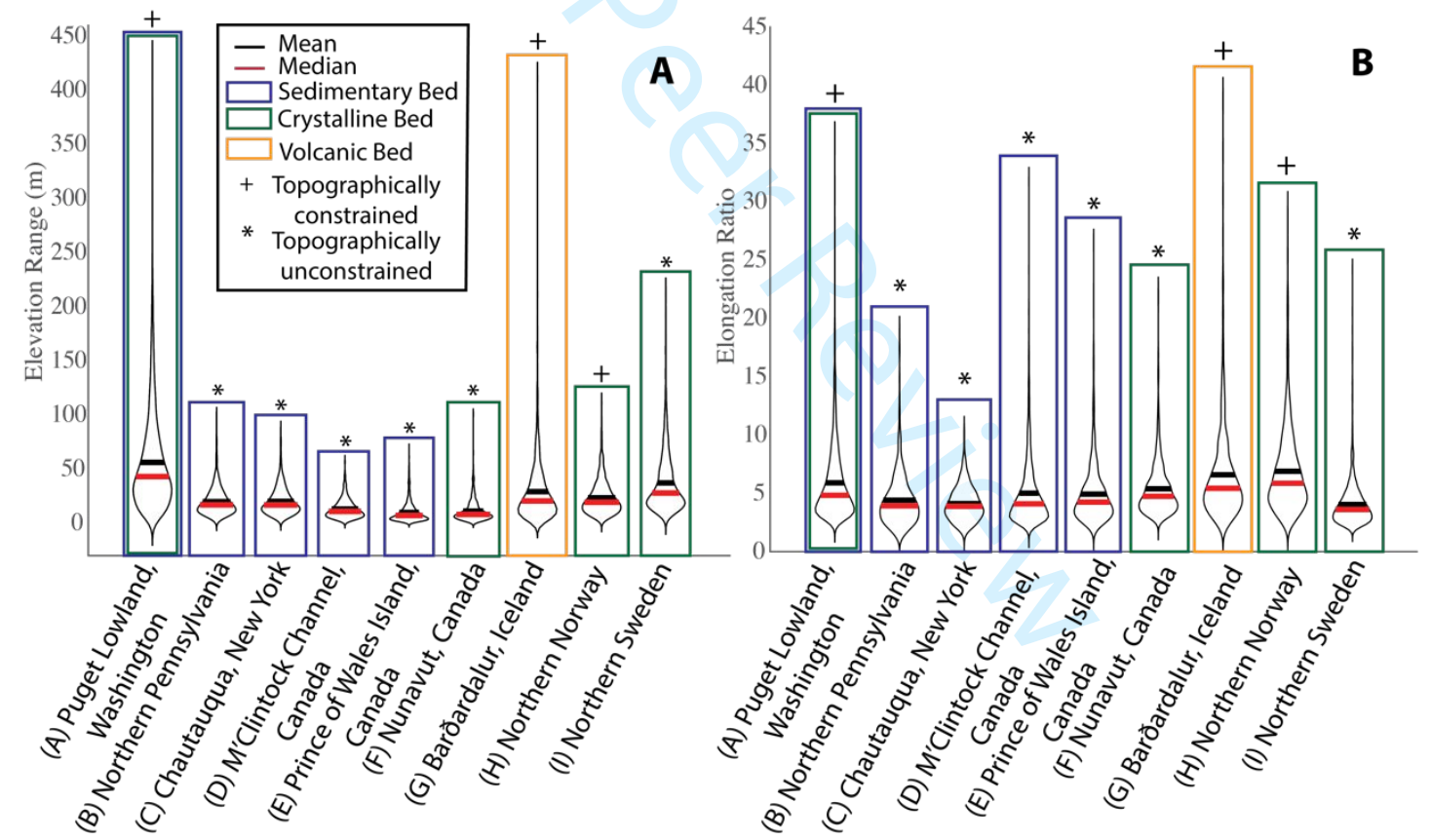

Figure 6: (A) Distribution of bedform post-glacial, contemporary elevation range and (B) distribution of bedform elongation ratios by site characterized by topography and bed substrate. MATLAB code for violin plot visualization provided by H. Hoffmann (2015).

280

\section{Bedform orientation and distribution}

While overall streamlined bedform orientation ranges vary by site depending on predominant direction of ice flow, the average parallel conformity (i.e., standard deviation of orientation) of all sites is 26 degrees (Figure 7). Multiple sites, including M'Clintock Channel (Site D) and Prince of Wales Island (Site E), have notable variations and crosscutting relationships between bedforms of different orientations, indicating two temporal flow orientations are preserved, although one 
flow orientation is far more prominent (Figures 2, 7). Two of the Norway (Site $\mathrm{H})$, have topographically-influenced variations in bedform

292 orientation (Figure 7).

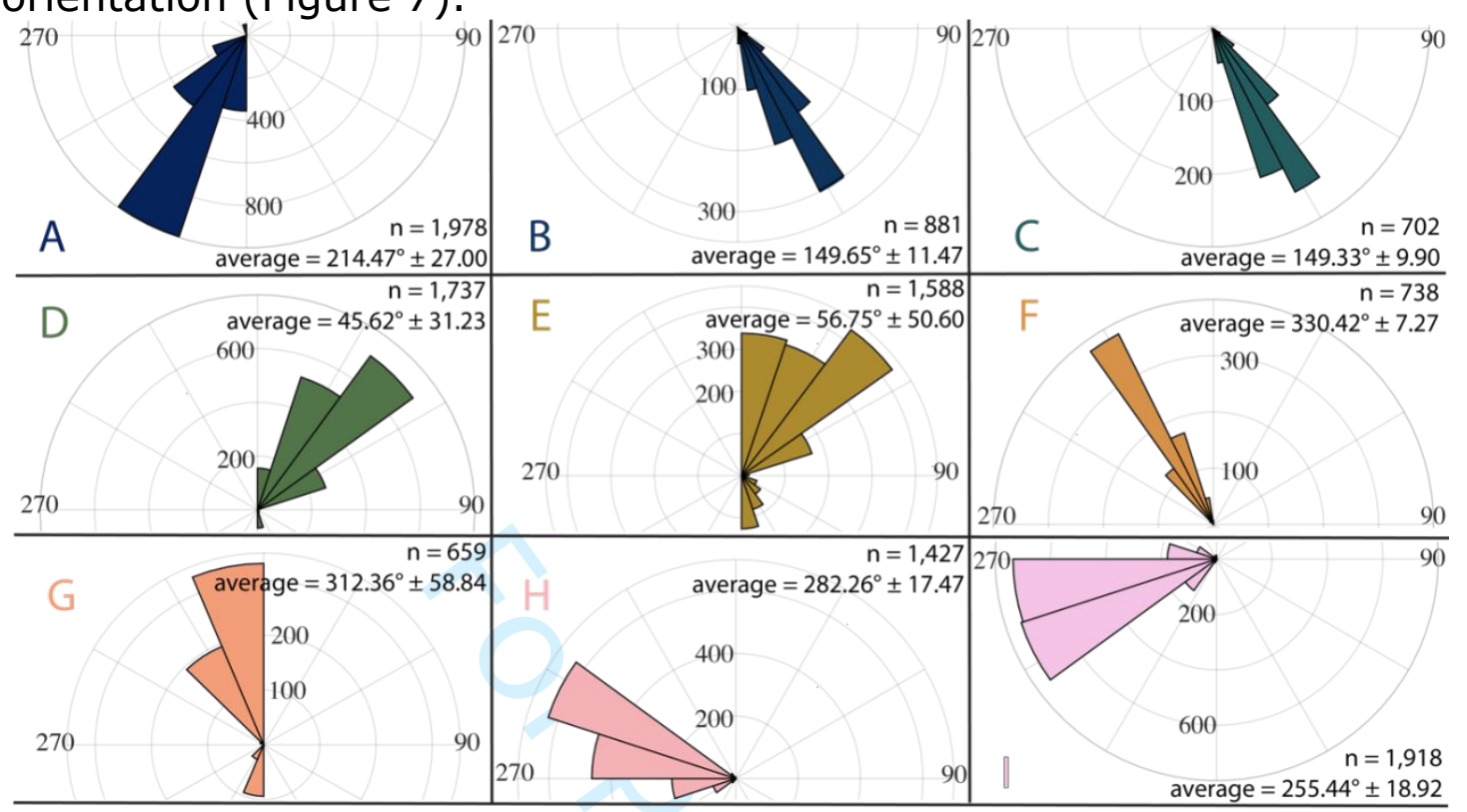

Figure 7: Orientations of mapped bedforms. (A) Puget Lowland, Washington, United States; (B) Northwestern Pennsylvania, United States; (C) Chautauqua, New York, United States; (D) M'Clintock Channel, Canada (two distinct ice flow directions); (E) Prince of Wales Island, Canada; (F) Nunavut, Canada; (G) Barðardalur, Iceland; (H) Northern Norway (two distinct ice flow directions); (I) Northern Sweden.

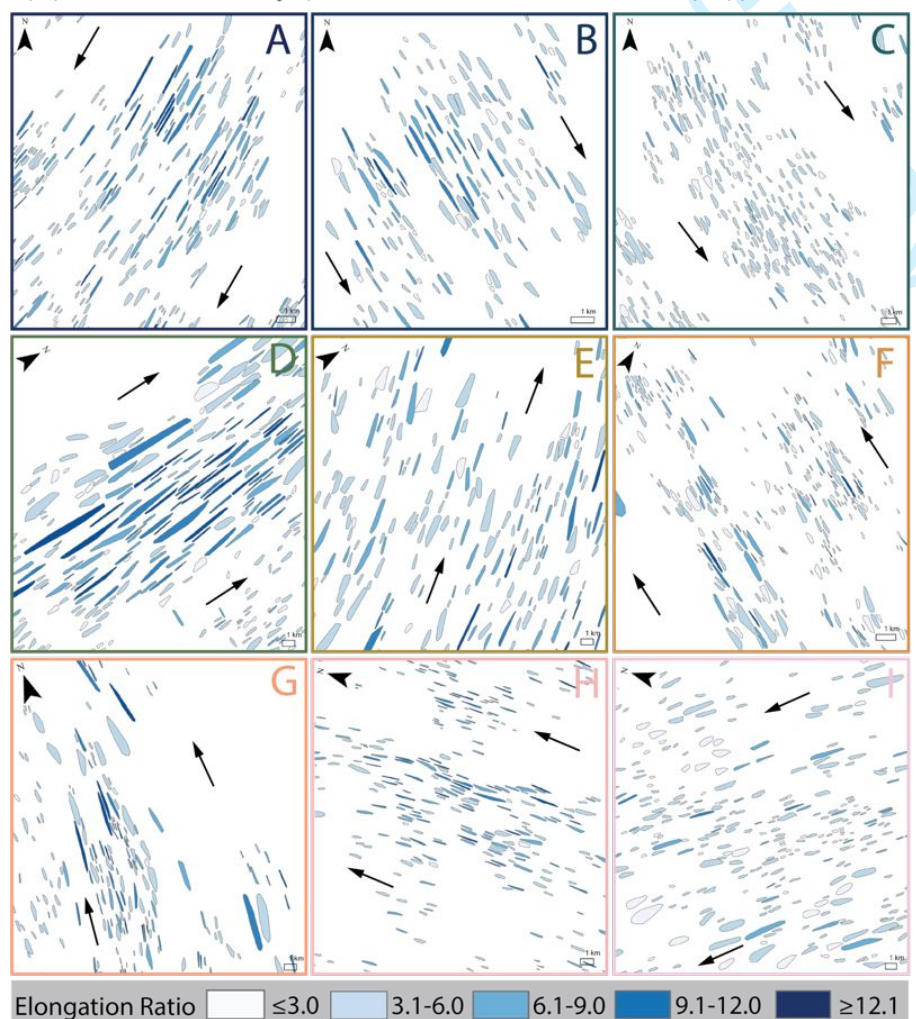

Figure 8: Representative bedform elongation ratios at (A) Puget Lowland, Washington, United States; (B) Northwestern Pennsylvania, United States; (C) Chautauqua, New York, United States; (D) M'Clintock Channel, Canada; (E) Prince of Wales Island, Canada; (F) Nunavut, Canada; (G) Bárðardalur, Iceland; (H) Northern Norway; (I) 
More elongate bedforms occur in swarms with higher density and

\section{Success of semi-automatic mapping streamlined bedforms in deglaciated landscapes \\ Previous morphometric studies of streamlined subglacial bedforms} have utilized Fourier spectra data (e.g., Spagnolo et al., 2017), manual identification (e.g., Principato et al., 2016), and object-oriented automatic identification (e.g., Saha et al., 2011), but these methods have not been systematically utilized for multiple geographic locations nor applied to multi-type bedform datasets. While TPI was originally developed to classify landscapes and delineate watersheds (Weiss, 2001; Tagil \& Jenness, 2008), its ability to characterize negative and positive relief features through slope variations is conceptually applicable to many landscapes. In the context of glacial landscapes, the distinct and similar elongate morphologies and occurrence of numerous bedforms in close proximity make streamlined subglacial bedforms well-suited for identification with TPI. The application of TPI within this study best identifies bedforms within elongation ratios between 1.1 and 39 (Figure 4 ), while low amplitude bedforms of $>15: 1$ elongation ratios are more difficult to map due to small and narrow slope differentiations. Many of the manually mapped bedforms were visually low-amplitude and/or highly elongate. Additionally, the two sites with the greatest number of manually mapped bedforms occurred in northern Norway (Site $\mathrm{H}$ ) and northern Sweden (Site I), where the landscapes appeared to be highly reworked or surficially imprinted by post-glacial processes (Table 2). In general, features that needed to be manually removed include non-glacial positive relief features such as modern river banks, fluvial valleys, and bedrock highs, identified by their location, size, orientation, or lack of any elongation.

The greatest number of bedforms per area were identified in the partially unlithified bed site of the Puget Lowland (Site A) and across lithified sedimentary beds including northwestern Pennsylvania (Site B), 
342 Chautauqua (Site C), and M'Clintock Channel (Site D). These sites also

343 had the lowest proportion of bedforms incorrectly identified by TPI as well

344 as the lowest number of bedforms manually mapped, indicating that unlithified and lithified sedimentary beds are best suited for semiautomatic mapping of subglacial streamlined bedforms. Conversely, the crystalline bedrock sites in northern Norway (Site $\mathrm{H}$ ) and northern Sweden (Site I) and volcanic bedrock site in Bárðardalur (Site G) had the greatest proportions of bedforms incorrectly identified by TPI and the largest fraction of their bedforms were identified manually (Table 2). TPI therefore does not perform as well on crystalline bedrock sites, potentially due to smaller relief changes that are not easily identified by the system.

\section{Sensitivity of ice streaming to variable bed conditions}

While sub-meter amplitude bedforms like bedrock striations are not resolved in the dataset presented here, meter to kilometer scale bedforms like drumlins, glacial lineations, and grooves are well resolved. Bedforms across the datasets have significant overlap and positive correlation between width and length (Figures 4, S1), indicating genetic similarity between bedforms regardless of whether they formed through erosional or depositional processes. Additionally, bedform length and width metrics are more frequently on the smaller side of the data while the largest length and width metrics are rare (Figure 4), however it is notable that the longest bedform in this dataset is not also the widest, which highlights processes of bedform elongation, leaving bedforms with high length values with relatively small widths (Puget Lowland (Site A)).

The multi-site, multi-type bedforms identified in this work, formed on different continental masses and by different ice sheets, are similar in morphology to the bedforms across single geographic regions and those binned as either depositional or erosional forms (e.g., Stokes and Clark, 2002; Saha et al., 2011; Spagnolo et al., 2014; Principato et al., 2016). This similarity in bedform morphologies, furthermore, supports the idea of genetic relationships between all streamlined subglacial bedforms. Novel to this study, we find a minimum length to width ratio (i.e. elongation) of $1.12: 1$ indicating that barely elongate bedforms are (1) resolved in the dataset and (2) occur at all observed scales as minimum bedform width and length values linearly increase across the dataset (Figure 4). This indicates a ubiquitous lower-size limit by which streamlined bedforms may be resolved in remote sensing data. The unimodal distribution around an elongation ratio of 5:1 and positive skewness in elongation seen in this work has also been found amongst other morphological bedform assessments (Figure 5; e.g., Saha et al., 2011; Spagnolo et al., 2014; Principato et al., 2016; Ely et al., 2016). This similarity suggests that the full range of bedform elongation represented by this dataset can occur at a multitude of sites regardless of bed topography and lithology or climatological and glaciological factors (Table 1). The minimum elongation threshold and similarity in elongation ranges across sites highlight a similarity of ice-bed interactions across "soft" and "hard" beds in both 
389 topographically confined and unconfined settings, suggesting a self-

390 organization of ice-bed processes regardless of site characteristics. The concept of streamlined bedforms developing as a self-organizing phenomenon is not novel in the field of glacial geomorphology and has been suggested to occur independently from local bed lithologic and topographic conditions (Spagnolo et al., 2017). From the similarities in bedform morphologies, we suggest regions of ice streaming exhibit potential for equivalent ice-flow velocities or persistence of ice-flow pathways regardless of bed character.

Topographically constrained sites produce bedforms with the highest mean and median elongation ratios with the most elongate bedforms of the overall dataset (Figure 6B; Table 1; Table 2).

Topographic constraint on ice flow results in topographic funneling and increased ice speed (Hindmarsh, 2001; Wellner et al., 2001; Hall \& Glasser, 2003; Ottesen et al., 2008; Roberts et al., 2010; Eyles et al., 2018). While bedform elongation is enhanced in regions that are topographically constrained, bedform elongation is not contingent on bedrock substrate (Figure 6B; Table 1; Table 2), which we interpret reflects a higher sensitivity of ice streaming velocity and persistence to bed topography than bed substrate (Stokes \& Clark, 2003; Winsborrow et al., 2010b; Halberstadt et al., 2016; Serrousi et al., 2017; Ignéczi et al., 2018; Greenwood et al., 2021). However, while bedform elongation is not contingent upon bedrock substrate, the topographically unconstrained and lithified sedimentary bed sites in Chautauqua (Site C) and northwestern Pennsylvania (Site B) have the least elongate bedforms, perhaps due to basal thermal regime or other glaciologic factors influencing bedform production.

We find that small, less elongate bedforms are inter-mixed with more elongate features and not found solely at the margins of mapped bedform swarms (Figure 9). An expectation of this observation is at M'Clintock Channel (Site D) where the largest, most elongate bedforms at this site are spatially centered in the mapped bedform swarm while the least elongate bedforms flank the lateral edges (Figure 8 ). This spatial organization likely represents a centralized zone of stronger ice streaming where lateral drag slowed ice flow along the edges.

In considering proximity to ice margin in relation to bedform elongation, while down-ice variations in elongation have been observed in other studies (e.g. Colgan \& Mickelson, 1997; Stokes and Clark, 2002), this variation is not observed in our nine study sites. We interpret this spatial uniformity of bedform elongation relative to ice margin (Figure 8 ) to be a result of ice-flow persistence, allowing all bedforms to become uniformly mature before ice retreat (Benediktsson et al., 2016).

Easily eroded beds within topographically constrained regions produce large variations in bedform surface relief (Figure 6), indicating the sensitivity of bedform relief to topographic setting despite variations in bed lithology. Across these topographically constrained and easily eroded bed substrates, more elongate bedforms correspond with smaller 
436

437

438

439

440

441

442

443

444

445

446

447

448

449

450

451

452

453

454

455

456

457

458

459

460

461

462

463

464

465

466

467

468

469

470

471

472

473

474

475

476

477

478

479

480

481

482

individual bedform relief (Figure 3 ). This pattern is an indication of iceflow persistence (Benediktsson et al., 2016): persistent processes of erosion and deposition at the ice-bed interface in conjunction with high ice velocities produce a more homogenized bedform feature. Conversely, at these same sites where bed conditions allow for great bedform elongation variability, the less elongate bedforms correlate with greater variability in bedform relief (Figure 3). Therefore, in regions where ice streaming is not as well established or ice velocities are relatively slow, erosion and depositional processes are more heterogeneous to result in uneven bedform relief. Topographically unconstrained sites with lithified sedimentary bed conditions create bedforms with the most uniform elongation and surface relief (Figure 6 ), indicating these regions are most suitable for persistent, low velocity ice streaming producing welldeveloped processes of erosion and deposition in the subglacial environment.

\section{Impact of ice-flow velocity and persistence on bedform properties and patterns}

Sedimentary bed sites, both lithified and mixed bed, have the greatest number of bedforms per area, suggesting greater potential for erosion and deposition of bed material (Tables 1,2 ). These qualitatively "soft", more easily eroded beds allow for greater production and transport of sediment to the ice margin. Conversely, "hard", crystalline beds are more resistant to erosion (Krabbendam et al., 2016; Eyles \& Doughty, 2016) and thus to sediment production and transport. The greatest number of bedforms per area, found on a mixed unlithified sedimentary bed system with crystalline bedrock, likely occur due to high availability of unlithified sediments and meltwater presence from strain heating. Strain heating occurs as ice flows over bedrock highs, collectively allowing for greater bed erosion, sediment deposition, and ice streaming. Lithified sedimentary beds were similarly densely populated with streamlined bedform features (Table 2). Crystalline and volcanic beds have the lowest bedform densities, suggesting that bed lithology, rather than topography, is a more dominant control on streamlined bedform density.

Regions with highly elongate bedforms correspond with qualitatively greater flow orientation organization (Figures 6, 8; Table 2). Spatially stable and/or persistent ice streaming conceptually contributes to spatial homogeneity in erosion and deposition processes leading to the formation of consistently orientated and shaped bedforms. Deviations to bedform orientation occur from both temporal and spatial variations, where bedforms can be preserved from multiple glaciations or across constrained topography, respectively. In the case of spatially influenced orientation, physical constraints on ice-flow direction in topographically constrained regions are more likely to have greater uniformity in bedform orientation, regardless of bed lithology or temporal switching of ice-flow direction like in Bárðardalur (Site G). Lithified sedimentary sites that are topographically unconstrained have some of the greatest bedform 
483

484

485

486

487

488

489

490

491

492

493

494

495

496

497

498

499

500

501

502

503

504

505

506

507

508

509

510

511

512

513

514

515

516

517

518

519

520

521

522

523

524

525

526

527

528

529

densities (Table 2), highest orientation uniformity (Table 2; Figures 7, 8), and smallest bedform relief and elongation as previously mentioned (Figure 6), further suggesting these settings are favorable for persistent ice streaming.

\section{CONCLUSIONS}

Despite a few shortcomings with low-amplitude, elongate subglacial bedforms and landscapes altered greatly by post-glacial processes, the application of TPI developed in this study highlights its widespread ability to quickly map thousands of bedforms with little computational time and less human error and subjectivity. This large, semi-automatically mapped dataset provides key insight into topographic and bed lithology controls on ice streaming that should be applied to understanding contemporary systems through systematically assessing erosional and depositional subglacial bedforms across nine deglaciated Northern Hemisphere sites (King et al., 2009).

From these results, we learn landform signatures of ice streaming have remarkable morphometric range similarities regardless of bed topography and lithology. All regions of ice streaming, measurable by the presence of streamlined bedforms, are capable of similar ice-flow velocities regardless of bed characteristics. However, sites with lithified and unlithified sedimentary beds contain the greatest number of bedforms per area, indicating bed lithology is a more dominant control on bedform spatial presence than regional topography. We also find topography has a first-order control on streamlined bedform elongation and subsequent ice stream velocity and/or ice flow persistence as evidenced by the role of topographic funneling (Hindmarsh, 2001; Wellner et al., 2001; Hall \& Glasser, 2003; Ottesen et al., 2008; Roberts et al., 2010; Eyles et al., 2018). Additionally, increased organization in ice flow orientation, indicated by bedform orientation and parallel conformity, appear to be characteristic of ice streams in topographically constrained regions. Conversely, topographically unconstrained lithified sedimentary beds support synthesis of bedforms with uniform elongation ratios, low bedform relief, uniform bedform orientation, and high bedform density, indicating these sites are most suitable for the development of persistent ice streaming with well organized subglacial erosive and depositional processes.

Due to the fundamental role of bed topography and substrate in determining ice dynamics (Clarke et al., 1977; Whillians \& van der Veen, 1997; Cuffey \& Paterson, 2010; Greenwood et al., 2021), assessment of streamlined bedform morphologies provides crucial information on bedrelated controls to ice flow (Stokes \& Clark, 2001, 2002; King et al., 2009). As contemporary ice streams continue to retreat across environments with variable topography and bed lithology, the use of preserved streamlined bedforms from paleo-subglacial environments is highly beneficial to constraining subglacial process sensitivities to variable bed conditions (e.g., Eyles et al., 2018; Greenwood et al., 2021). 


\section{REFERENCES}

Alley, R.B., Blankenship, D.D., Bentley, C.R., \& Rooney, S.T. (1986). Deformation of till beneath ice stream B, West Antarctica. Nature, 322, 57-59.

Bamber, J., \& Aspinall, W. (2013). An expert judgement assessment of future sea level rise from the ice sheets. Nature Climate Change, 3(4), 424-427.

Bourgeois, O., Dauteuil, O., \& Vliet-Lanoë, B. V. (2000). Geothermal control on flow patterns in the Last Glacial Maximum ice sheet of Iceland. Earth Surface Processes and Landforms: The Journal of the British Geomorphological Research Group, 25(1), 59-76.

Briner, J. P. (2007). Supporting evidence from the New York drumlin field that elongate subglacial bedforms indicate fast ice flow. Boreas, 36(2), 143-147.

Bromwich, D.H., Toracinta, E.R., Oglesby, R.J., Fastook, J.L., \& Hughes, T.J. (2005). LGM Summer Climate on the Southern Margin of the Laurentide Ice Sheet: Wet or Dry? Journal of Climate, 18, 33173338.

Cazenave, P. W., Lambkin, D. O., \& Dix, J. K. (2008, September). Quantitative bedform analysis using decimetre resolution swath bathymetry. In CARIS 2008 International User Group Conference. Clallam County, Olympic Department of Natural Resources, Washington Department of Transportation. (2008). Puget Lowlands 2005 [data file]. Retrieved from https://lidarportal.dnr.wa.gov/\#47.85003:122.92053:7

Clark, C. D. (1993). Mega-scale glacial lineations and cross-cutting ice-flow landforms. Earth surface processes and landforms, 18(1), 129.

Clark, C.D. (1997). Reconstructing the evolutionary dynamics of former ice sheets using multi-temporal evidence, remote sensing and GIS. Quaternary Science Reviews, 16(9), 1067-1092.

Clark, C.D. (1999). Glaciodynamic context of subglacial bedform generation and preservation. Annals of Glaciology, 28, 23-32.

Clark, C.D., Evans, D.J.A. and Piotrowski, J.A. (2003) Palaeo-ice streams: an introduction. Boreas, 32(1), 1-3.

Clarke, G.K.C., Nitsan, U., \& Paterson, W.S.B. (1977). Strain heating and creep instability in glaciers and ice sheets. Reviews of Geophysics, $15(2), 129-255$.

Colgan, P.M., \& Mickelson, D.M. (1997). Genesis of streamlined landforms and flow history of the Green Bay lobe, Wisconsin, USA. Sedimentary Geology, 111, 77-25.

Cuffey, K., \& Paterson, W.S.B. (2010). The Physics of Glaciers. Elsevier.

De Rydt, J., Gudmundsson, G.H., Corr, H.F.J., \& Christoffersen, P. (2013). Surface undulations of Antarctic ice streams tightly controlled by bedrock topography. Cryosphere, 7, 407-417. 
Dethier, D., Pessl, F., Keuler, R., Balzarini, M., \& Pevear, D. (1995). Late Wisconsinan glaciomarine deposition and isostatic rebound, northern Puget Lowland, Washington. Geological Society of America Bulletin, 107(11), 1288-1303.

Easterbrook, D.J. (1992). Advance and retreat of Cordilleran ice sheets in Washington, U.S.A. Geographic Physique et Quaternaire, 46(1), 5168.

Ely, J., Clark, C., Spagnolo, M., Stokes, C., Greenwood, S., Hughes, A., Dunlop, P. \& Hess, D. (2016). Do subglacial bedforms comprise a size and shape continuum?. Geomorphology, 257, 108-119.

Evans, D., Phillips, E., Hiemstra, J., \& Auton, C. (2006) Subglacial till: Formation, sedimentary characteristics and classification. EarthScience Reviews, 78(1-2), 115-176.

Eyles, N., \& Doughty, M. (2016). Glacially-streamlined hard and soft beds of the paleo-Ontario ice stream in Southern Ontario and New York state. Sedimentary Geology, 338, 51-71.

Eyles, N., Arbelaez Moreno, L., \& Sookhan, S. (2018). Ice streams of the Late Wisconsin Cordilleran Ice Sheet in western North America.

Quaternary Science Reviews, 179, 87-122.

Falcini, F.A.M., Rippin, D.M., Krabbendam, M., \& Selby, K.A. (2018). Quantifying bed roughness beneath contemporary and palaeo-ice streams. Journal of Glaciology, 64(247), 822-834.

Favier, L., Pattyn, F., Berger, S., \& Drews, R. (2016). Dynamic influence of pinning points on marine ice-sheet stability: a numerical study in Dronning Maud Land, East Antarctica. European Geosciences Union, 10(6).

Fowler, A. C. (2010). The formation of subglacial streams and mega-scale glacial lineations. Proceedings of the Royal Society A: Mathematical, Physical and Engineering Sciences, 466(2123), 3181-3201.

Greenwood, S.L., Simkins, L.M., Winsborrow, M.C.M., \& Bjarnadóttir, L.R. (2021). Exceptions to bed-controlled ice sheet flow and retreat from glaciated continental margins worldwide. Science Advances, 7(3).

Halberstadt, A., Simkins, L., Greenwood, S., Anderson, J. (2016) Past icesheet behaviour: Retreat scenarios and changing controls in the Ross Sea, Antarctica. Cryosphere, 10(3), 1003-1020.

Hall, A. M., \& Glasser, N. F. (2003). Reconstructing the basal thermal regime of an ice stream in a landscape of selective linear erosion: Glen Avon, Cairngorm Mountains, Scotland. Boreas, 32(1), 191-207.

Hijmans, R. J., Cameron, S. E., Parra, J. L., Jones, P. G., \& Jarvis, A. (2005). Very high resolution interpolated climate surfaces for global land areas. International Journal of Climatology, 25, 1965-1978.

Hindmarsh, R.C.A. (2001). Influence of channelling on heating in icesheet flows. Geophysical Research Letters, 28(19), 3681-3684.

Hoffmann H, 2015: violin.m - Simple violin plot using matlab default kernel density estimation. INRES (University of Bonn), Katzenburgweg 5, 53115 Germany. hhoffmann@uni-bonn.de 
622

623

624

625

626

627

628

629

630

631

632

633

634

635

636

637

638

639

640

641

642

643

644

645

646

647

648

649

650

651

652

653

654

655

656

657

658

659

660

661

662

663

664

665

666

667

668

Hughes, A., Clark, C., \& Jordan, C. (2010). Subglacial bedforms of the last British Ice sheet. Journal of Maps, 6, 543-563.

Hughes, P., Gibbard, P., \& Ehlers, J. (2013) Timing of glaciation during the last glacial cycle: Evaluating the concept of a global 'Last Glacial Maximum' (LGM). Earth-Science Reviews, 125, 171-198.

Ignéczi, Á., Sole, A.J., Livingstone, S.J., Ng, F.S.L., \& Yang, K. (2018). Greenland Ice Sheet Surface Topography and Drainage Structure Controlled by the Transfer of Basal Variability. Frontiers in Earth Science, 6(101).

King, E., Hindmarsh, R., \& Stokes, C. (2009). Formation of mega-scale glacial lineations observed beneath a West Antarctic ice stream. Nature Geoscience, 2(8), 585-588.

Kleman, J., \& Borgström, I. (1996). Reconstruction of palaeo-ice sheets: The use of geomorphological data. Earth Surface Processes and Landforms, 21(10), 893-909.

Kleman, J. Hättestrand, C., Stroeven, A.P., Jansson, K.N., Angelis, H.D., \& Borgström, I. (2006). Reconstruction of Palaeo-Ice Sheets- Inversion of their Glacial Geomorphological Record. Glacier Science and Environmental Change, 192-198.

Krabbendam, M., Eyles, N., Putkinen, N., Bradwell, T., \& ArbelaezMoreno, L. (2016). Streamlined hard beds formed by palaeo-ice streams: A review. Sedimentary Geology, 338, 24-50.

Maier, N., Humphrey, N., Harper, J., \& Meierbachtol, T. (2019). Sliding dominates slow-flowing margin regions, Greenland Ice Sheet. Science Advances, 5.

Margold, M., Stokes, C. R., \& Clark, C. D. (2018). Reconciling records of ice streaming and ice margin retreat to produce a palaeogeographic reconstruction of the deglaciation of the Laurentide Ice Sheet. Quaternary science reviews, 189, 1-30.

McKenzie, M., Simkins, L., \& Princiapto, S. (2021). Streamlined subglacial bedforms across the deglaciated Northern Hemisphere, PANGAEA Data Archiving \& Publication.

McIntyre, N.F. (1985). The Dynamics of Ice-Sheet Outlets. Journal of Glaciology, 31(108), 99-107.

Ng, F.S.L. (1998). Mathematical Modelling of Subglacial Drainage and Erosion. Unpublished thesis, St. Catherine's College, Oxford.

Nienow, P., Sole, A., Slater, D., Cowton, T. (2017). Recent Advances in Our Understanding of the Role of Meltwater in the Greenland Ice Sheet System. Current Climate Change Reports, 3(4), 330-344.

Ottesen, D., Stokes, C.R., Rise, L., \& Olsen, L. (2008). Ice-sheet dynamics and ice streaming along the coastal parts of northern Norway. Quaternary Science Reviews, 27(9-10), 922-940.

ORNL DAAC Circumpolar Arctic Vegetation, Geobotanical, Physiographic Maps, 1982-2003

Payne, A., \& Dongelmans, P. (1997) Self-organization in the thermomechanical flow of ice sheets. Journal of Geophysical Research B: Solid Earth, 102(6), 12219-12233. 
669

670

671

672

673

674

675

676

677

678

679

680

681

682

683

684

685

686

687

688

689

690

691

692

693

694

695

696

697

698

699

700

701

702

703

704

705

706

707

708

709

710

711

712

713

714

Pohjola, V.A., \& Hedfors, J. (2003). Studying the effects of strain heating on glacial flow within outlet glaciers from the Heimefrontfjella Range, Dronning Maud Land, Antarctica. Annals of Glaciology, 37, 134-142.

Porter, C., Morin, P., Howat, I., Noh, M. J., Bates, B., Peterman, K., Keesey, S., Schlenk, M., Gardiner, J., Tomko, K., Willis, M., Kelleher, C., Cloutier, M., Husby, E., Foga, S., Nakamura, H., Platson, M., Wethington, M.. Williamson, C., Bauer, G., Enos, J., Arnold, G.,; Kramer, W., Becker, P., Doshi, A., D'Souza, C., Cummens, P., Laurier, F., Bojesen, M., 2018, "ArcticDEM", https://doi.org/10.7910/DVN/OHHUKH, Harvard Dataverse, V1.

Principato, S. Moyer, A., Hampsch, A., \& Ipsen, H. (2016). Using GIS and streamlined landforms to interpret palaeo-ice flow in northern Iceland. Boreas, 45(3), 470-482.

Rignot, E., Mouginot, J., Scheuchl, B., van den Broeke, M., van Wessem, M.J., \& Morlighem, M. (2019). Four decades of Antarctic Ice Sheet mass balance from 1979-2017. Proceedings of the National Academy of Sciences of the United States of America,116(4), 1095-1103.

Rippin, D.M., Vaughan, D.G., \& Corr, H.F.J. (2011). The basal roughness of Pine Island Glacier, West Antarctica. Journal of Glaciology, 57(201), 67-77.

RNL DAAC Circumpolar Arctic Vegetation, Geobotanical, Physiographic Maps, 1982-2003.

Roberts, D. H., Long, A. J., Davies, B. J., Simpson, M. J., \& Schnabel, C. (2010). Ice stream influence on west Greenland ice sheet dynamics during the last glacial maximum. Journal of Quaternary Science, 25(6), 850-864.

Saha, K., Wells, N., \& Munro-Stasiuk, M. (2011). An object-oriented approach to automated landform mapping: A case study of drumlins. Computers and Geosciences, 37(9), 1324-1336.

Schoof, C., \& G., Clarke. (2008). A model for spiral flows in basal ice and the formation of subglacial flutes based on a Reiner-Rivlin rheology for glacial ice. Journal of Geophysical Research: Solid Earth, 11395).

Seguinot, J., Khroulev, C., Rogozhina, I., Stroeven, A.P., \& Zhang, Q. (2014). The effect of climate forcing on numerical simulations of the Cordilleran ice sheet at the Last Glacial Maximum. The Cryosphere, 8, 1087-1103.

Sevon, W.D., \& Barun, D.D. (2000). Glacial Deposits of Pennsylvania. Commonwealth of Pennsylvania Department of Conservation and Natural Resources Bureau of Topographic and Geologic Survey. Map 59.

Shaw, J., Pugin, A., \& Young, R.R. (2008). A meltwater origin for Antarctic shelf bedforms with special attention to megalineations. Geomorphology, 102(3-4), 364-375.

Siegert, M.J., \& Dowdeswell, J.A. (2004). Numerical reconstructions of the Eurasian Ice Sheet and climate during the Late Weichselian. Quaternary Science Reviews 23(11-13), 1273-1283. 
Siegert, M.J., Taylor, J., Payne, A.J. (2005). Spectral roughness of subglacial topography and implications for former ice-sheet dynamics in East Antarctica. Global and Planetary Change, 45, 249-263. Spagnolo, M., Clark, C. D., Ely, J. C., Stokes, C. R., Anderson, J. B., Andreassen, K., ... \& King, E. C. (2014). Size, shape and spatial arrangement of mega-scale glacial lineations from a large and diverse dataset. Earth Surface Processes and Landforms, 39(11), 1432-1448. Spagnolo, M., Bartholomaus, T., Clark, C., Stokes, C., Atkinson, N., Dowdeswell, J., Ely, J., Graham, A., Hogan, K., King, E., Larter, R., Livingstone, S., \& Pritchard, H. (2017). The periodic topography of ice stream beds: Insights from the Fourier spectra of mega-scale glacial lineations. Journal of Geophysical Research: Earth Surface, 122(7), 1355-1373.

Stokes, C. R., \& Clark, C. D. (2001). Palaeo-ice streams. Quaternary Science Reviews, 20(13), 1437-1457.

Stokes, C. R., \& Clark, C. D. (2002). Are long subglacial bedforms indicative of fast ice flow?. Boreas, 31(3), 239-249.

Stokes, C. R., \& Clark, C. D. (2003). The Dubawnt Lake palaeo-ice stream: evidence for dynamic ice sheet behaviour on the Canadian Shield and insights regarding the controls on ice-stream location and vigour. Boreas, 32(1), 263-279.

Stokes, C. R., Spagnolo, M., Clark, C. D., Cofaigh, C. Ó., Lian, O. B., \& Dunstone, R. B. (2013). Formation of mega-scale glacial lineations on the Dubawnt Lake Ice Stream bed: 1. size, shape and spacing from a large remote sensing dataset. Quaternary Science Reviews, 77, 190209.

Swanson, T.W., \& Caffee, M.L. (2001). Determination of ${ }^{36} \mathrm{Cl}$ Production Rates Derived from the Well-Dated Deglaciation Surfaces of Whidbey and Fidalgo Islands, Washington. Quaternary Research, 56(3), 366-382.

Tagil, S. \& Jenness, J. (2008). GIS-Based Landform Classification and Topographic, Landcover and Geologic Attributes of Landforms Around the Yazoren Polje, Turkey. Journal of Applied Sciences, 8(6), 910-921. Doi: 10.3923/jas. 2008.910.921

Tulaczyk, S., Lamb, W.B., \& Engelhardt, H.F. (2000). Basal mechanics of Ice Stream B, West Antarctica 1. Till mechanics. Journal of Geophysical Research, 105(B1), 463-481.

United States Geological Survey. (1999). 7.5 minute Digital Elevation Model (10 meter resolution) [data file]. Retrieved from https://apps.nationalmap.gov/viewer/

United States Geological Survey. (2000). 7.5 minute digital elevation models (DEM) for Pennsylvania 10 meter [data file]. Retrieved from http://www.pasda.psu.edu/

Wang, S., Wu, Q., Ward, D. (2017). Automated delineation and characterization of drumlins using a localized contour tree approach. Int J Appl Earth Obs Geoinformation, 62, 144-156. 
761

762

763

764

765

766

767

768

769

770

771

772

773

774

775

Weertman, J. (1957). On the sliding of glaciers. Journal of Glaciology, $3(21), 33-38$.

Weiss, A.D. (2001). Topographic Position and Landforms Analysis. The Nature Conservancy, poster.

Wellner, J.S., Lowe, A.L., Shipp, S.S., \& Anderson, J.B. (2001).

Distribution of glacial geomorphic features on the Antarctic continental shelf and correlation with substrate: implications for ice behavior. Journal of Glaciology, 47(158), 397-411.

Whillans, I.M., \& van der Veen, C.J. (1997). The role of lateral drag in the dynamics of Ice Stream B, Antarctica. Journal of Glaciology, 43(144), 231-238.

Winsborrow, M.C.M., Clark, C.D., \& Stokes, C.R. (2010b). What controls the location of ice streams? Earth-Science Reviews, 103(1-2), 45-59.

\section{SUPPORTING ONLINE ONLY INFORMATION}

elongation width $\Delta$ elev. length lithology

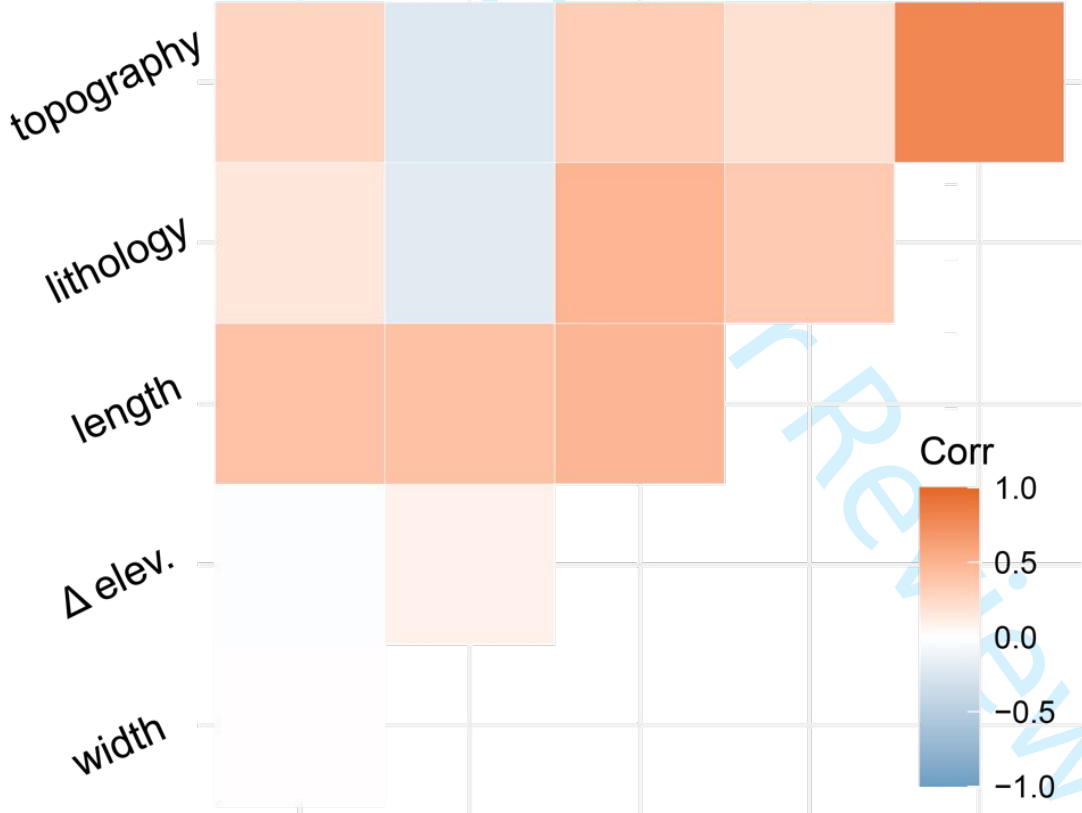

S1: Correlation matrix of all 11,628 bedform features. 

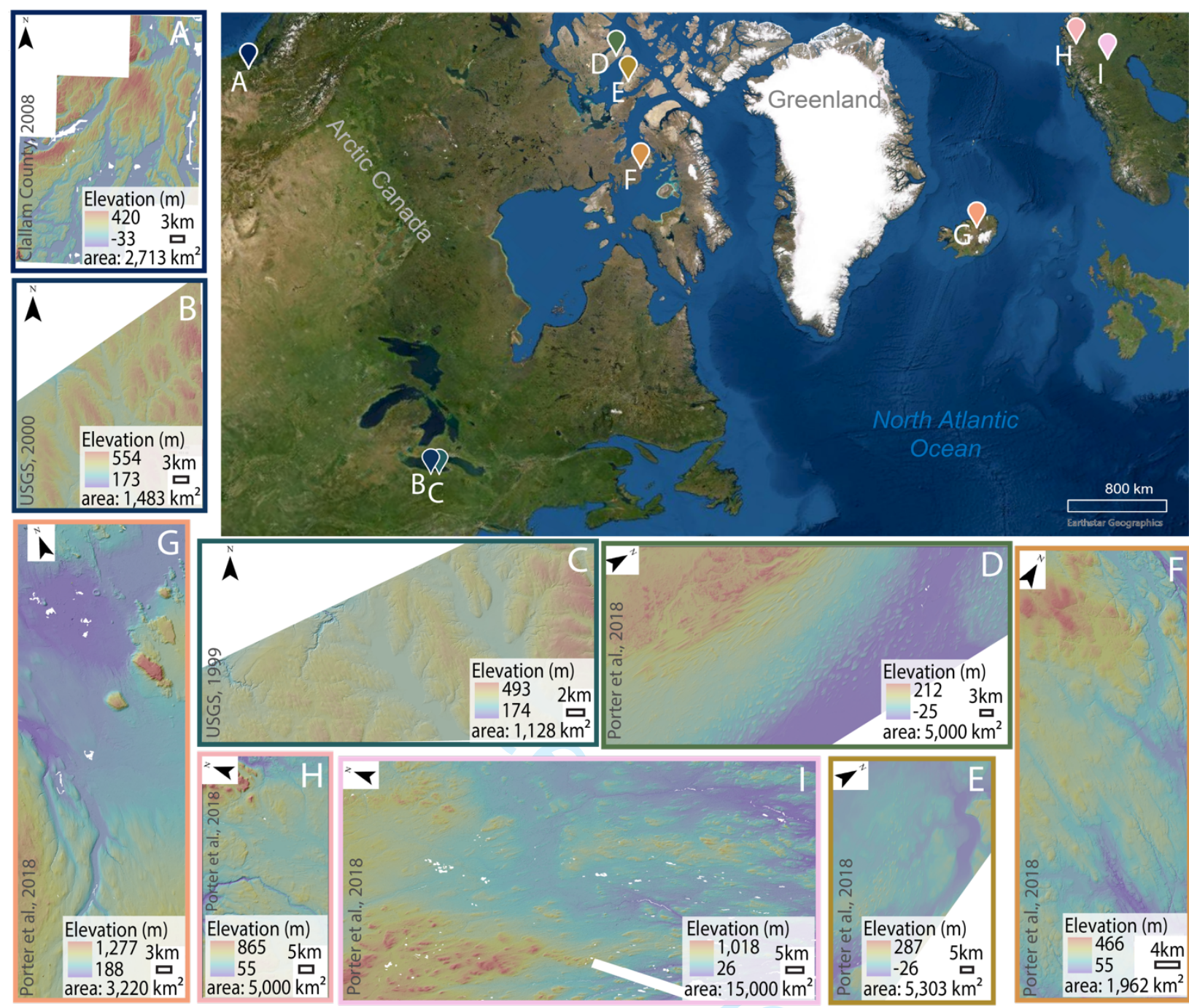

Figure 1: Study sites including (A) Puget Lowland, Washington, United States; (B) Northwestern Pennsylvania, United States; (C) Chautauqua, New York, United States; (D) M'Clintock Channel, Canada; (E) Prince of Wales Island, Canada; (F) Nunavut, Canada; (G) Bárðardalur, Iceland; (H) Northern Norway; (I) Northern Sweden. 

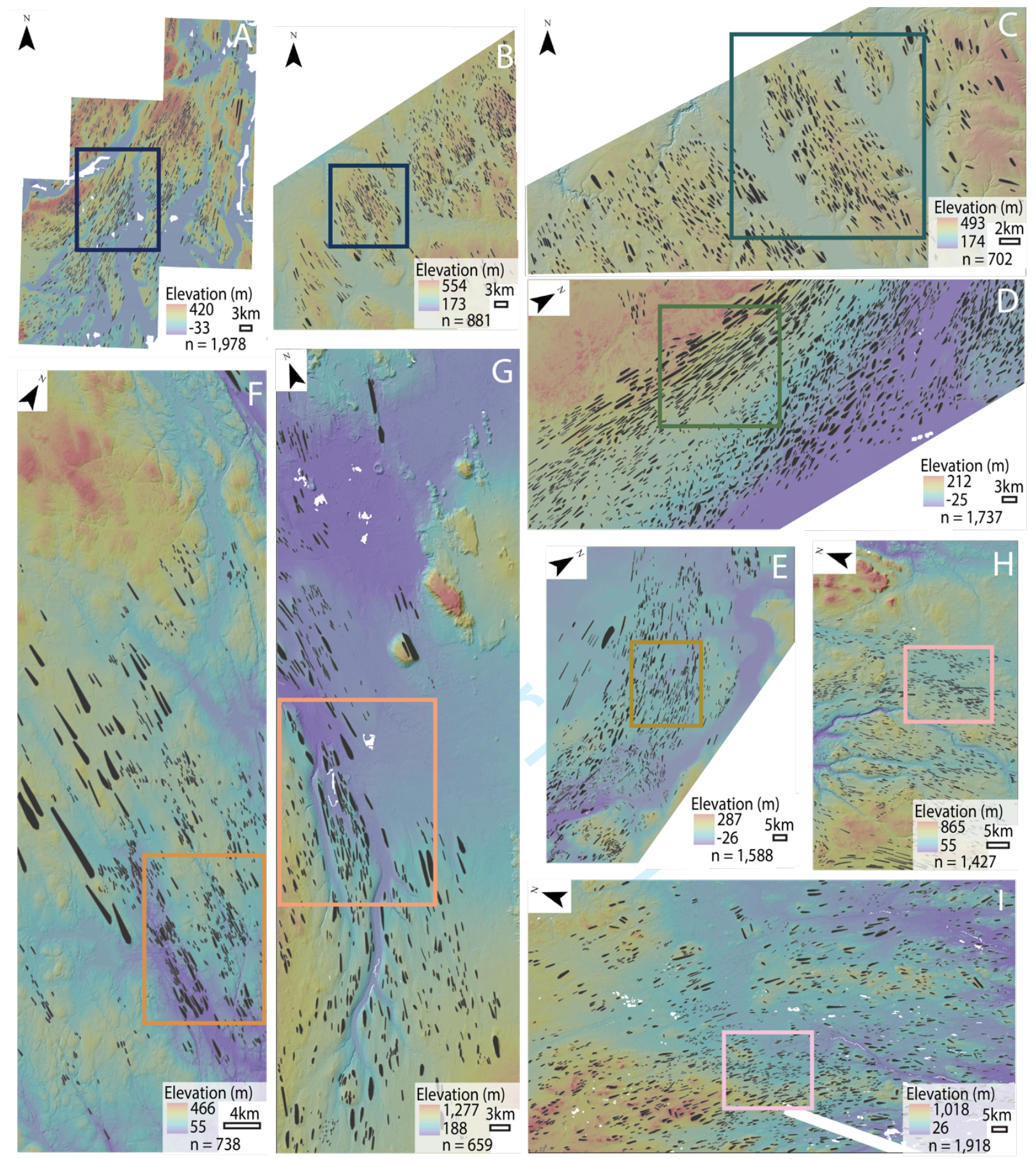

Figure 2: Mapped streamlined bedforms (black polygons) using topographic position index (TPI) methodology. Sites include (A) Puget Lowland, Washington, United States; (B) Northwestern Pennsylvania, United States; (C) Chautauqua, New York, United States; (D) M'Clintock Channel, Canada; (E) Prince of Wales Island, Canada; (F) Nunavut, Canada; (G) Bárðardalur, Iceland; (H) Northern Norway; (I) Northern Sweden. Colored insets indicate elongation distribution, pictured in Figure 9. 

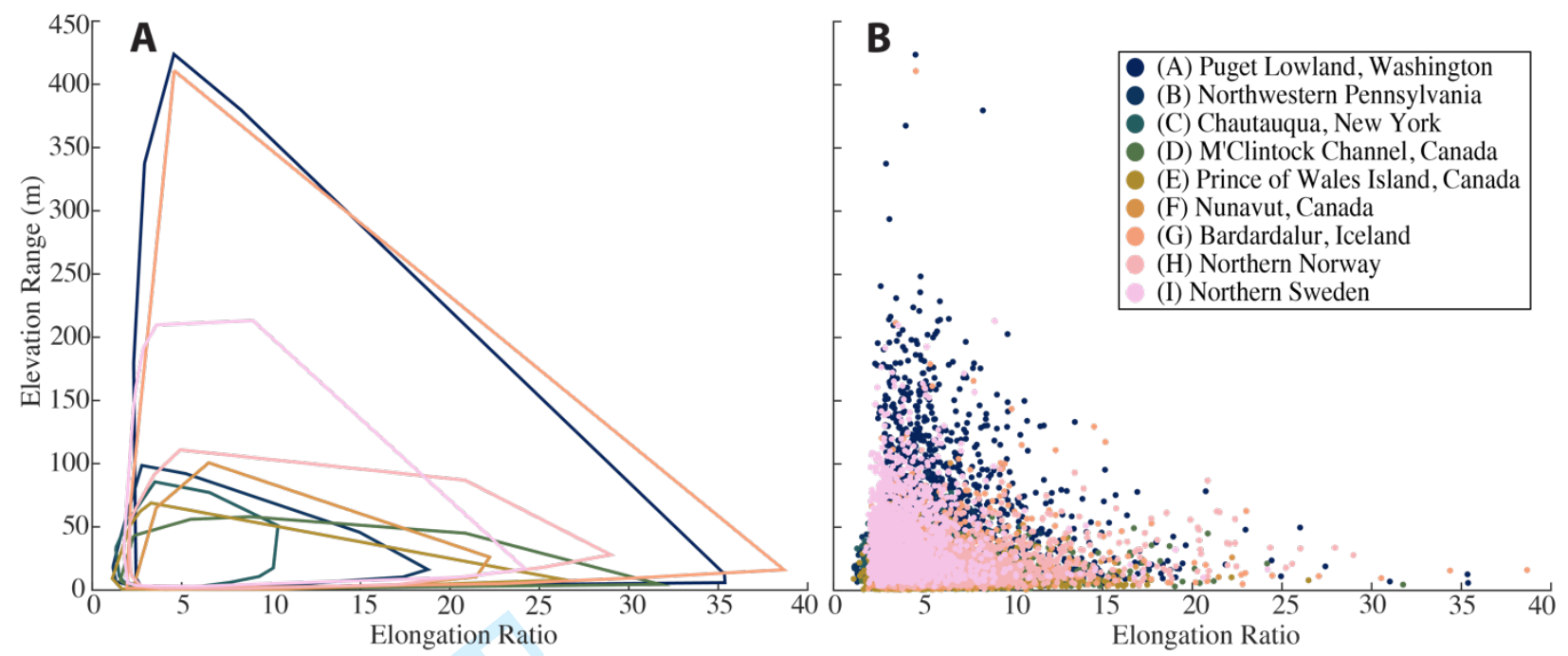

Figure 3: All bedform elongation ratio and elevation range metrics: (A) convex hull area of site data and (B) scatterplot of all data. More elongate bedforms correspond with smaller bedform elevation range. Greater differences in bedform elevation correspond with lower elongation ratio values.

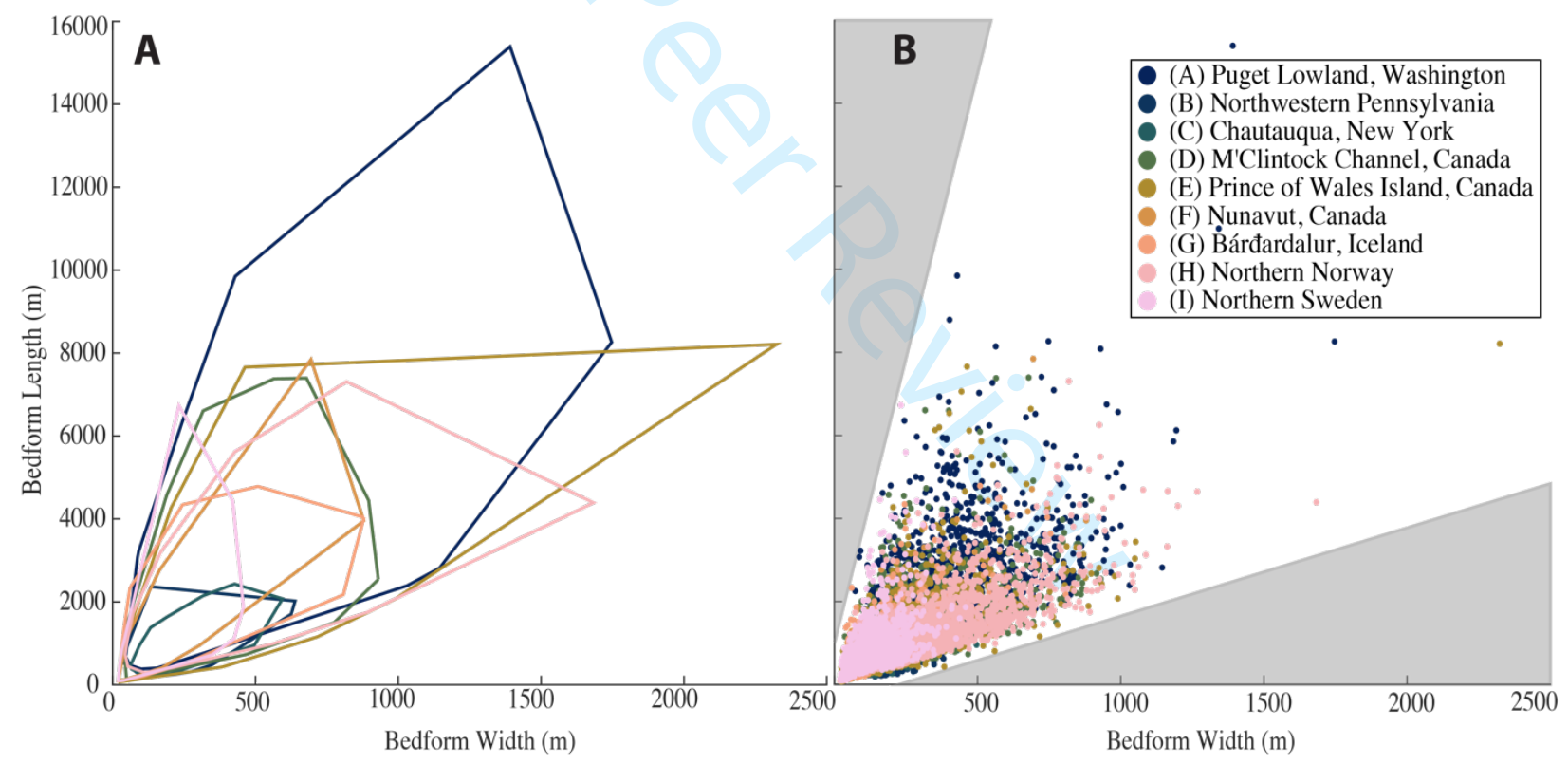

Figure 4: All bedform length and width metrics plotted by site: (A) convex hull area of site data and (B) scatterplot of all data, gray areas indicate regions where bedforms are not observed. Natural bedform threshold elongation ratio of less than 2:1 length:width can be detected in both representations of data. The mean and standard deviation of all bedform widths is $219 \pm 123 \mathrm{~m}$ while mean and standard deviation of all bedform lengths is $1,052 \pm 700 \mathrm{~m}$. Additional morphometric information for each site can be found in Table 2 . 


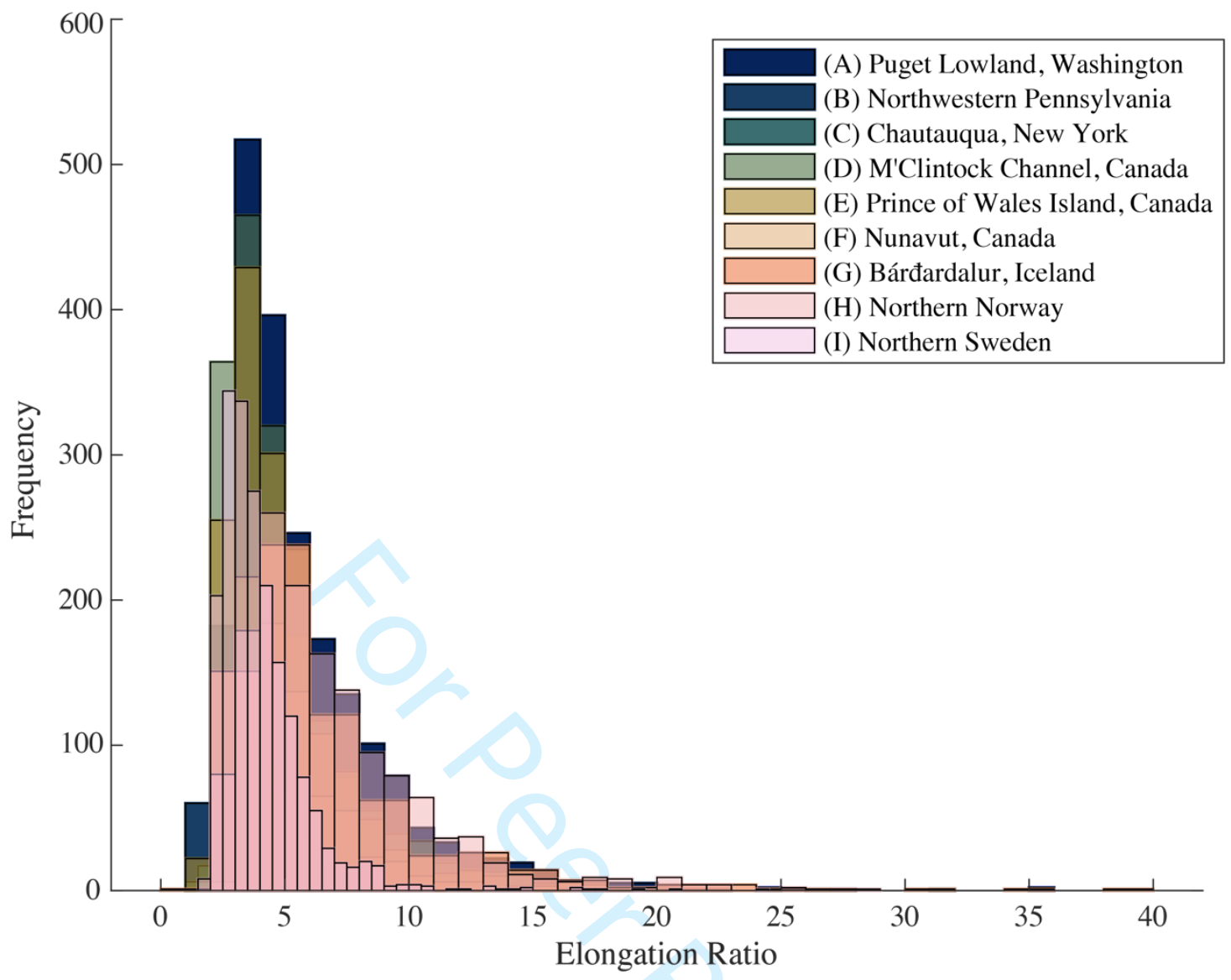

Figure 5: Frequency of bedform elongation ratios show a positively skewed curve with an average median of $5.26(n=11,628)$. All sites have remarkably similar bedform elongation range and distribution. Additional morphometric information for each site can be found in Table 2 . Site-specific histogram bins were calculated through the MATLAB "histogram algorithm" utilizing site-specific minimum and maximum elongation values. 


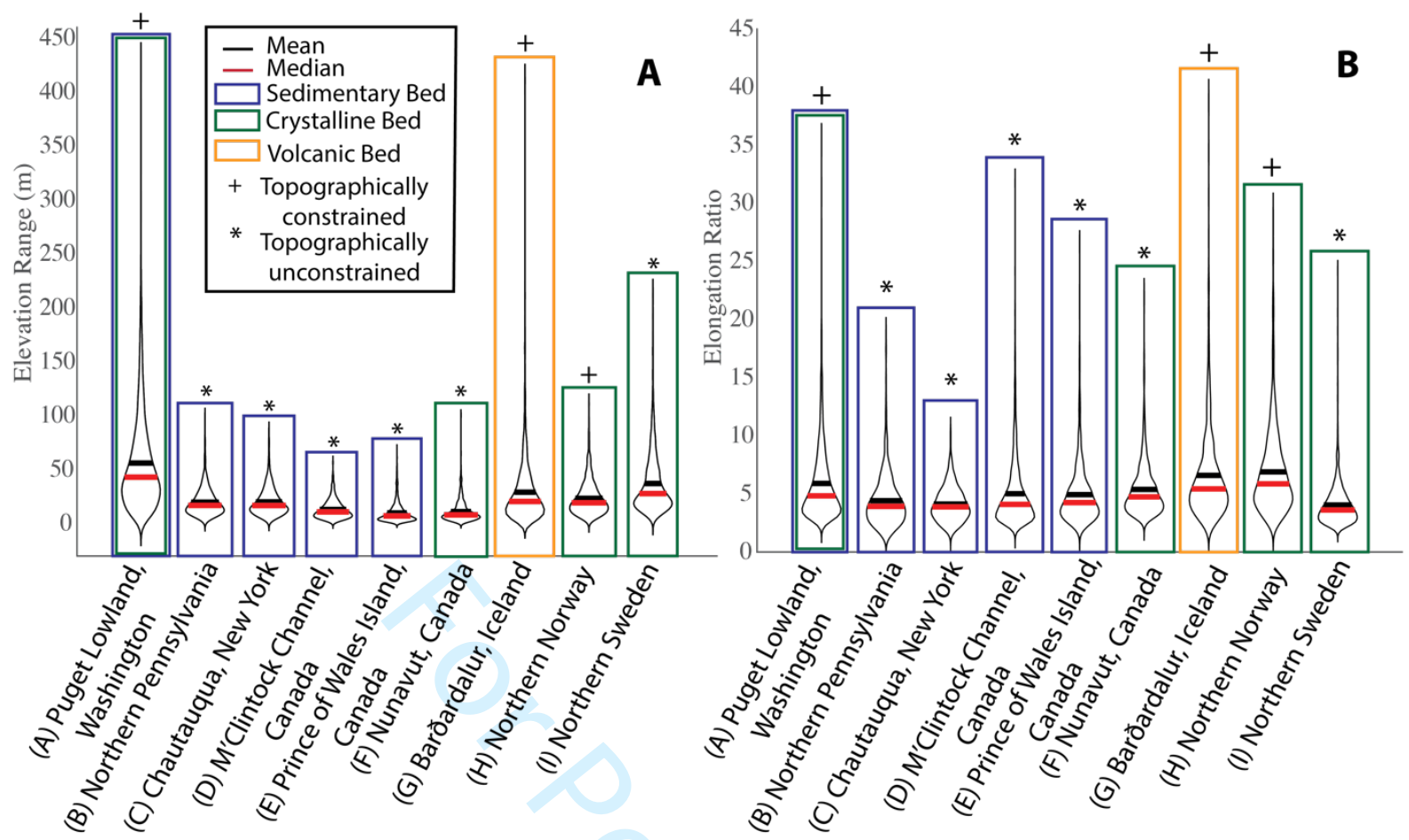

Figure 6: (A) Distribution of bedform post-glacial, contemporary elevation range and (B) distribution of bedform elongation ratios by site characterized by topography and bed substrate. MATLAB code for violin plot visualization provided by H. Hoffmann (2015).

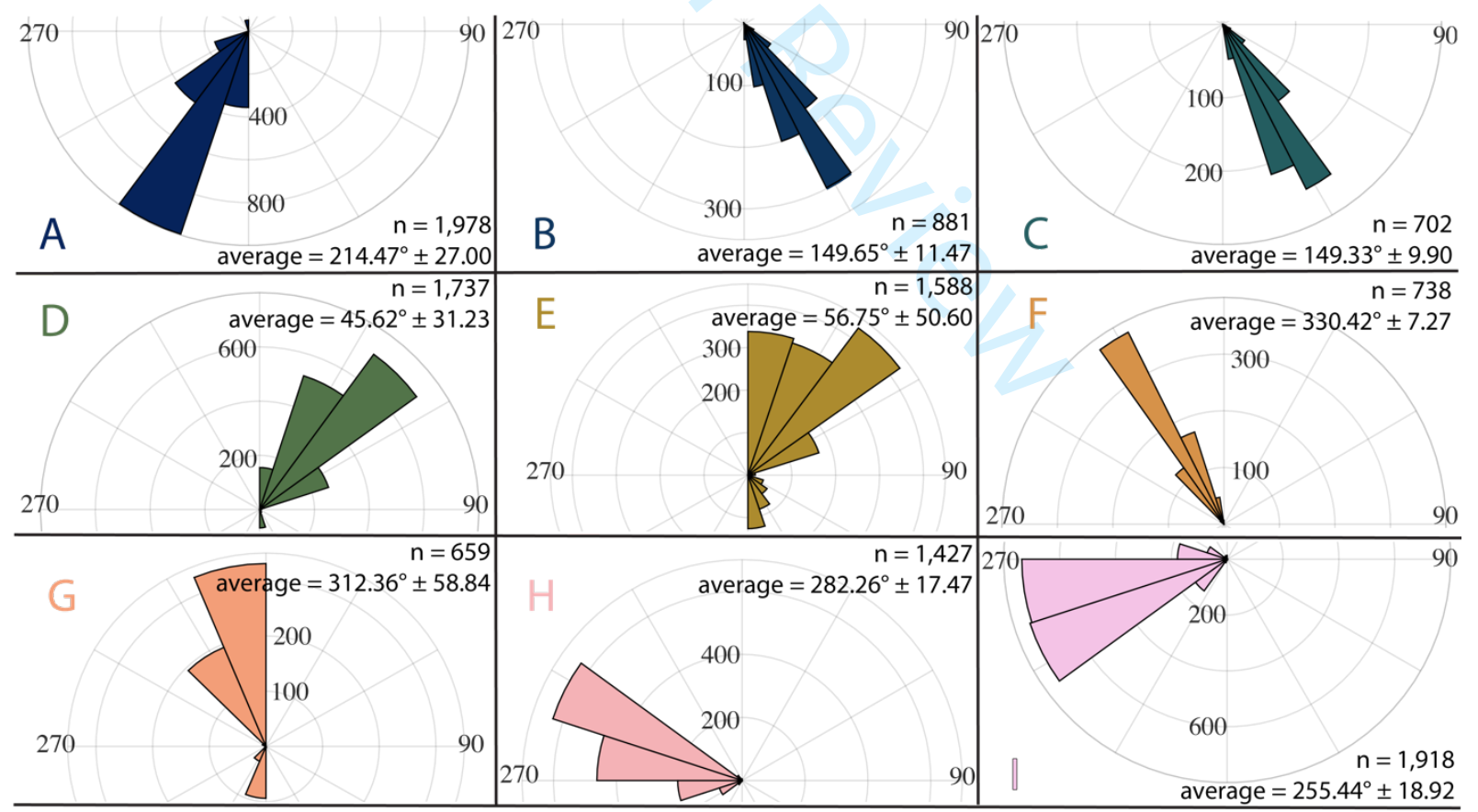

Figure 7: Orientations of mapped bedforms. (A) Puget Lowland, Washington, United States; (B) Northwestern Pennsylvania, United States; (C) Chautauqua, New York, United States; (D) M'Clintock Channel, Canada (two distinct ice flow directions); (E) Prince of Wales Island, Canada; (F) Nunavut, Canada; (G) Barðardalur, Iceland; (H) Northern Norway (two distinct ice flow directions); (I) Northern Sweden. 


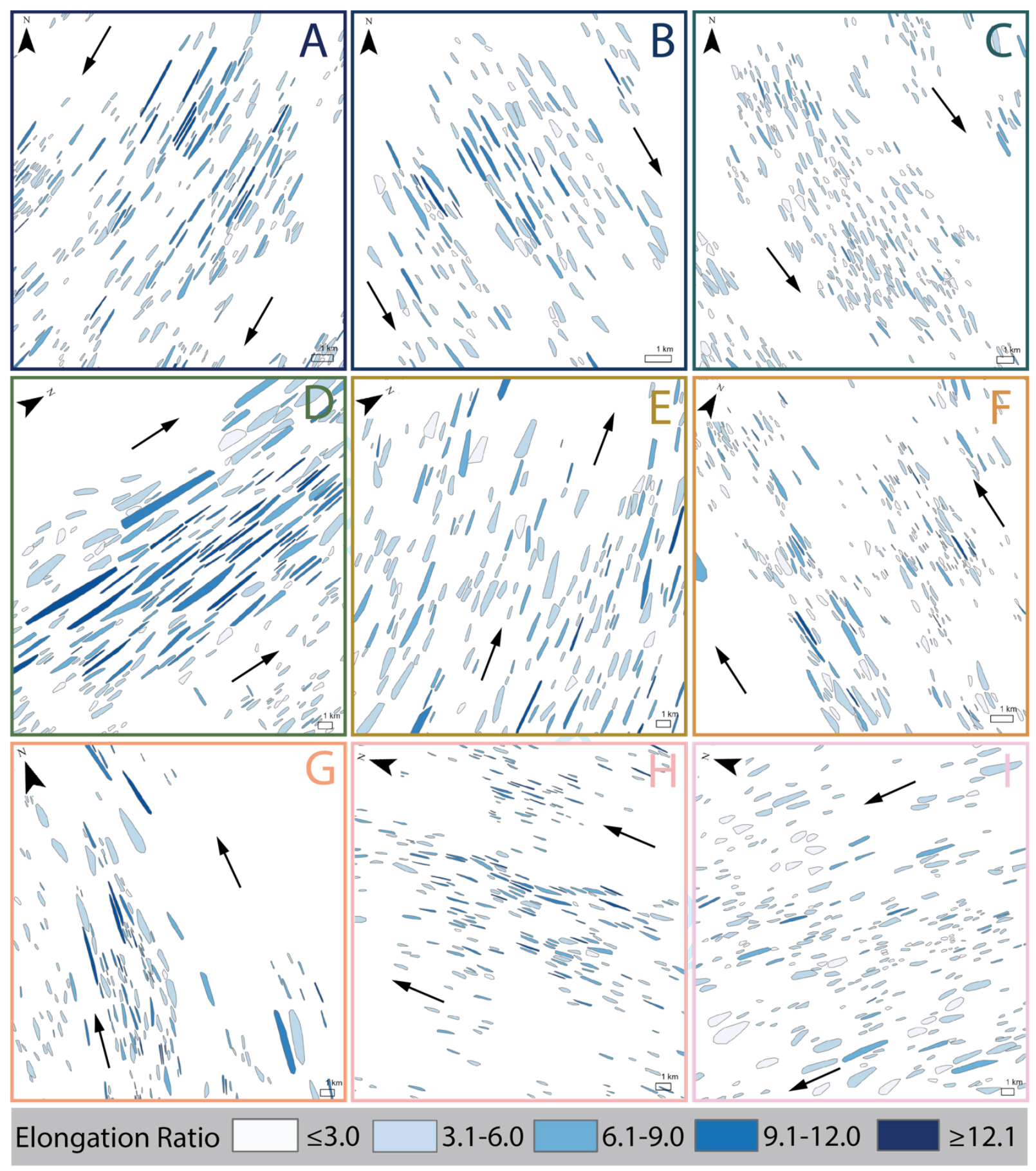

Figure 8: Representative bedform elongation ratios at (A) Puget Lowland, Washington, United States; (B) Northwestern Pennsylvania, United States; (C) Chautauqua, New York, United States; (D) M'Clintock Channel, Canada; (E) Prince of Wales Island, Canada; (F) Nunavut, Canada; (G) Bárðardalur, Iceland; (H) Northern Norway; (I) Northern Sweden. Black arrows indicate ice flow direction. 
Table 1: Site descriptions and data information.

\begin{tabular}{|c|c|c|c|c|c|c|c|c|}
\hline Sites & $\begin{array}{l}\text { Latitude } \\
\text { (decimal } \\
\text { degrees) }\end{array}$ & Bed setting & $\begin{array}{l}\text { Topographic } \\
\text { setting }\end{array}$ & Glacial history & $\begin{array}{l}\text { LGM climate } \\
\text { conditions }\end{array}$ & $\begin{array}{l}\text { Land } \\
\text { surface } \\
\text { area }\left(\mathrm{km}^{2}\right)\end{array}$ & $\begin{array}{l}\text { Vertical } \\
\text { resolution } \\
\text { (m) }\end{array}$ & $\begin{array}{l}\text { Horizontal } \\
\text { resolution } \\
(\mathrm{m} \times \mathrm{m})\end{array}$ \\
\hline $\begin{array}{l}\text { (A) Puget } \\
\text { Lowland, } \\
\text { Washington } \\
\text { State }\end{array}$ & 47.3507 & mixed & constrained & $\begin{array}{l}\text { ice free from the Cordilleran } \\
\text { Ice Sheet for } 16.5 \mathrm{ky} \text { a,b,c, } \\
\text { near ice margin, marine } \\
\text { terminating }\end{array}$ & $\begin{array}{l}\text { maritime, complex } \\
\text { seasonal climate } \\
\text { shifts }^{\mathrm{d}, \mathrm{e}}\end{array}$ & 2,713 & 2 & $1.83 \times 1.83$ \\
\hline $\begin{array}{l}\text { (B) } \\
\text { Northwestern } \\
\text { Pennsylvania }\end{array}$ & 41.9456 & $\begin{array}{l}\text { lithified } \\
\text { sedimentary bed }\end{array}$ & unconstrained & $\begin{array}{l}\text { ice free from the Laurentide } \\
\text { Ice Sheet for } 17 \mathrm{ky}^{f} \text {, near } \\
\text { ice margin, terrestrially } \\
\text { terminating }\end{array}$ & $\begin{array}{l}\text { continental, stable } \\
\text { climate }^{9}\end{array}$ & 1,483 & 10 & $30 \times 30$ \\
\hline $\begin{array}{l}\text { (C) Chautauqua, } \\
\text { New York }\end{array}$ & 42.2263 & $\begin{array}{l}\text { lithified } \\
\text { sedimentary bed }\end{array}$ & unconstrained & $\begin{array}{l}\text { ice free from the Laurentide } \\
\text { Ice Sheet for } 17 \mathrm{ky}^{f} \text {, near } \\
\text { ice margin, terrestrially } \\
\text { terminating }\end{array}$ & $\begin{array}{l}\text { continental } \\
\text { climate, high } \\
\text { winds }^{g}\end{array}$ & 1,128 & 10 & $30 \times 30$ \\
\hline $\begin{array}{l}\text { (D) M'Clintock } \\
\text { Channel, } \\
\text { Canada }\end{array}$ & 72.6689 & $\begin{array}{l}\text { lithified } \\
\text { sedimentary bed }\end{array}$ & unconstrained & $\begin{array}{l}\text { ice free from the Laurentide } \\
\text { Ice Sheet for at least } 9 \mathrm{ky}^{\mathrm{h}} \text {, } \\
\text { interior ice stream }\end{array}$ & $\begin{array}{l}\text { continental } \\
\text { climate }^{g}\end{array}$ & 5,000 & 2 & $2 \times 2$ \\
\hline $\begin{array}{l}\text { (E) Prince of } \\
\text { Wales Island, } \\
\text { Canada }\end{array}$ & 72.3189 & $\begin{array}{l}\text { lithified } \\
\text { sedimentary bed }\end{array}$ & unconstrained & $\begin{array}{l}\text { ice free from the Laurentide } \\
\text { Ice Sheet for } 7 \mathrm{ky}^{\mathrm{h}} \text {, interior } \\
\text { ice stream }\end{array}$ & $\begin{array}{l}\text { continental } \\
\text { climate }^{\mathrm{g}}\end{array}$ & 5,303 & 2 & $2 \times 2$ \\
\hline $\begin{array}{l}\text { (F) Nunavut, } \\
\text { Canada }\end{array}$ & 69.4173 & crystalline bed & unconstrained & $\begin{array}{l}\text { ice free from the Laurentide } \\
\text { lce Sheet for } 7 \mathrm{ky}^{\mathrm{h}} \text {, interior } \\
\text { ice stream }\end{array}$ & $\begin{array}{l}\text { continental } \\
\text { climate, high } \\
\text { winds }^{g}\end{array}$ & 1,962 & 2 & $2 \times 2$ \\
\hline $\begin{array}{l}\text { (G) Bárđardalur, } \\
\text { Iceland }\end{array}$ & 65.3055 & volcanic bed & constrained & $\begin{array}{l}\text { ice free from the Icelandic } \\
\text { Ice Sheet for } 14 \mathrm{ky}^{\mathrm{h}} \text { near } \\
\text { ice margin, marine } \\
\text { terminating }\end{array}$ & maritime climate & 3,220 & 2 & $2 \times 2$ \\
\hline $\begin{array}{l}\text { (H) Northern } \\
\text { Norway }\end{array}$ & 69.0897 & crystalline bed & constrained & $\begin{array}{l}\text { ice free from the } \\
\text { Fennoscandian Ice Sheet } \\
\text { for at least } 18 \mathrm{ky}^{\mathrm{h}} \text {, near ice } \\
\text { margin, marine terminating }\end{array}$ & maritime climate & 5,000 & 2 & $2 \times 2$ \\
\hline $\begin{array}{l}\text { (l) Northern } \\
\text { Sweden }\end{array}$ & 67.1265 & crystalline bed & unconstrained & $\begin{array}{l}\text { ice free from the } \\
\text { Fennoscandian Ice Sheet } \\
\text { for at least } 18 \mathrm{ky}^{\mathrm{h}} \text {, interior } \\
\text { ice stream }\end{array}$ & maritime climate & 15,000 & 2 & $2 \times 2$ \\
\hline
\end{tabular}

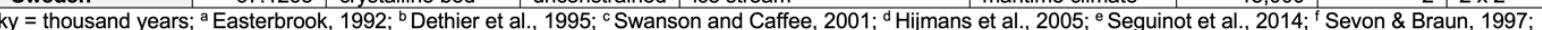

${ }^{9}$ Bromwich et al., 2005; ' ORNL DAAC Circumpolar Arctic Vegetation, 1982-2003; 'Margold et al., 2018; ' Siegert and Dowdeswell, 2004

Table 2: Bedform data by site including mapping statistics and bedform metrics.

\begin{tabular}{|c|c|c|c|c|c|c|c|}
\hline Sites & $\begin{array}{l}\text { Number of } \\
\text { bedforms (number } \\
\text { removed; number } \\
\text { added) }\end{array}$ & $\begin{array}{l}\text { Bedforms } \\
\text { per } 10 \mathrm{~km}^{2}\end{array}$ & $\begin{array}{l}\text { Ratio of } \\
\text { manually } \\
\text { added } \\
\text { bedforms: } \\
\text { final } \\
\text { bedforms }\end{array}$ & $\begin{array}{l}\text { Average } \\
\text { length } \pm \\
\text { standard } \\
\text { deviation }\end{array}$ & $\begin{array}{l}\text { Average } \\
\text { width } \pm \\
\text { standard } \\
\text { deviation }\end{array}$ & $\begin{array}{l}\text { Average } \\
\text { elongation }\end{array}$ & $\begin{array}{l}\text { Average } \\
\text { orientation } \pm \\
\text { parallel } \\
\text { conformity }\end{array}$ \\
\hline (A) Puget Lowland, Washington State & $1,978(512 ; 401)$ & 7.3 & $0.2: 1$ & $2,013 \pm 1,261$ & $365 \pm 180$ & 5.9 & $214 \pm 27$ \\
\hline (B) Northwestern Pennsylvania & $881(774 ; 60)$ & 5.9 & $0.07: 1$ & $666 \pm 342$ & $162 \pm 69$ & 4.4 & $330 \pm 11$ \\
\hline (C) Chautauqua, New York & $702(493 ; 103)$ & 6.2 & $0.1: 1$ & $652 \pm 337$ & $164 \pm 77$ & 4.1 & $329 \pm 10$ \\
\hline (D) M'Clintock Channel, Canada & $1,737(333 ; 615)$ & 3.5 & $0.4: 1$ & $1,259 \pm 789$ & $278 \pm 153$ & 5.0 & $46 \pm 31$ \\
\hline (E) Prince of Wales Island, Canada & $1,588(1,657 ; 665)$ & 3.0 & $0.4: 1$ & $1,054 \pm 882$ & $224 \pm 162$ & 4.9 & $57 \pm 51$ \\
\hline (F) Nunavut, Canada & $738(>800 ; 155)$ & 3.8 & $0.2: 1$ & $617 \pm 614$ & $115 \pm 88$ & 5.4 & $150 \pm 7$ \\
\hline (G) Bárđardalur, Iceland & $659(745 ; 326)$ & 2.1 & $0.5: 1$ & $1,006 \pm 701$ & $175 \pm 125$ & 6.6 & $132 \pm 59$ \\
\hline (H) Northern Norway & $1,427(526 ; 783)$ & 2.9 & $0.5: 1$ & $842 \pm 580$ & $132 \pm 68$ & 6.9 & $102 \pm 17$ \\
\hline (I) Northern Sweden & $1,918(2,241 ; 858)$ & 1.3 & $0.5: 1$ & $1,324 \pm 794$ & $346 \pm 187$ & 4.1 & $255 \pm 19$ \\
\hline
\end{tabular}




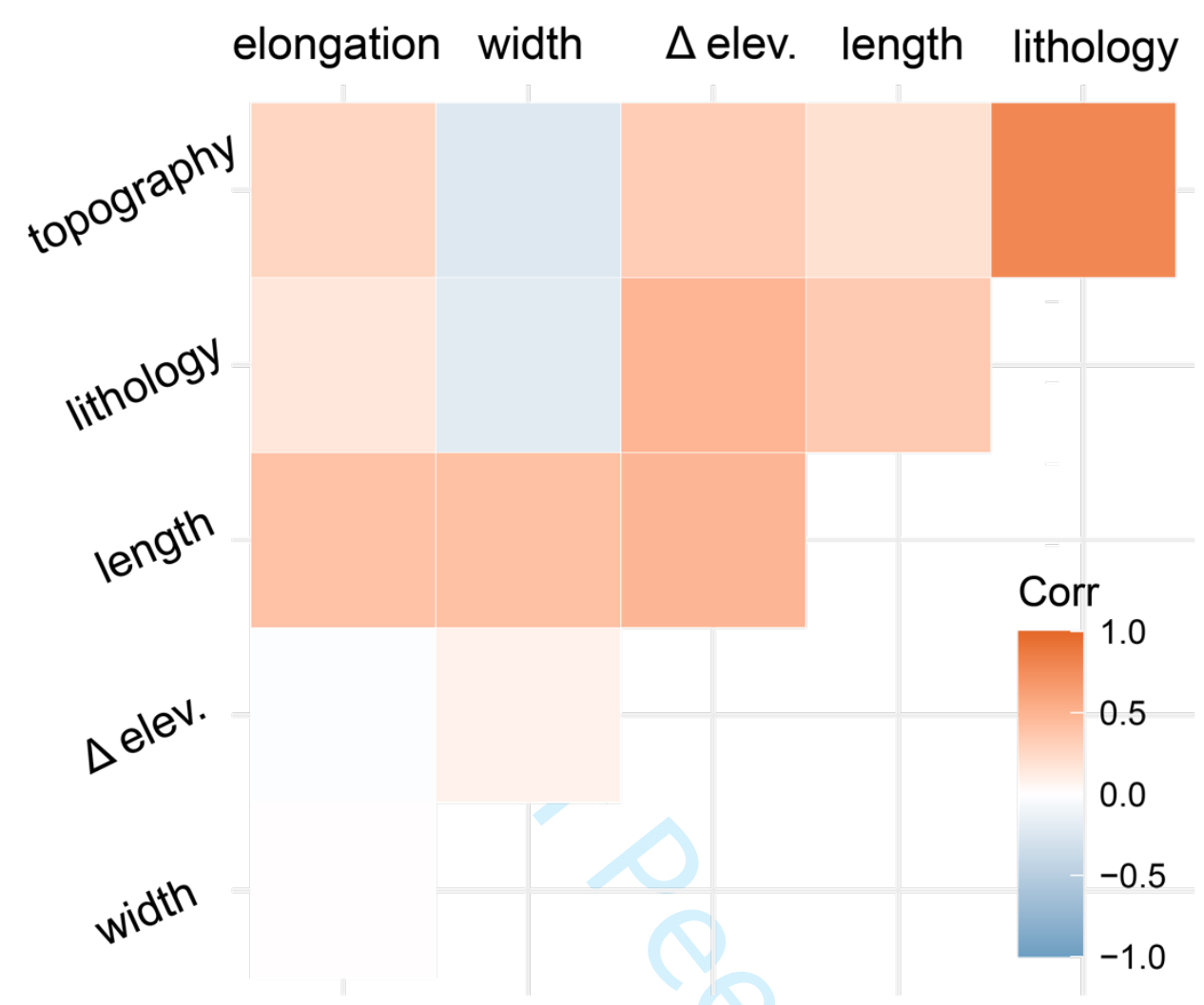

S1: Correlation matrix of all 11,628 bedform features. 